\title{
A PLACE OF BURNING: Hero or Ancestor Cult at Troy
}

\section{Author(s): Carolyn Chabot Aslan}

Source: Hesperia: The Journal of the American School of Classical Studies at Athens, Vol. 80, No. 3 (July-September 2011), pp. 381-429

Published by: The American School of Classical Studies at Athens

Stable URL: http://www.jstor.org/stable/10.2972/hesperia.80.3.0381

Accessed: 31-05-2017 06:25 UTC

\section{REFERENCES}

Linked references are available on JSTOR for this article:

http://www.jstor.org/stable/10.2972/hesperia.80.3.0381 ?seq=1\&cid=pdfreference\#references_tab_contents

You may need to log in to JSTOR to access the linked references.

JSTOR is a not-for-profit service that helps scholars, researchers, and students discover, use, and build upon a wide range of content in a trusted digital archive. We use information technology and tools to increase productivity and facilitate new forms of scholarship. For more information about JSTOR, please contact support@jstor.org.

Your use of the JSTOR archive indicates your acceptance of the Terms \& Conditions of Use, available at http://about.jstor.org/terms

The American School of Classical Studies at Athens is collaborating with JSTOR to digitize, preserve and extend access to Hesperia: The Journal of the American School of Classical Studies at Athens 
HESPERIA 80 (2OII)

Pages $38{ }^{-4} 429$

\section{A PLACE OF BURNING}

\author{
Hero or Ancestor Cult \\ AT Troy
}

1. Blegen 1932, pp. 441-444;

Troy III, pp. 394-396, figs. 285-287;

Troy IV, p. 299. I would like to thank many members of the team at Troy for their help, including Maureen Basedow, Ralf Becks, Gebhard Bieg, Pavol Hnila, Peter Jablonka, Moni Möck-Aksoy, Penelope Mountjoy, Wendy Rigter, and

\section{ABSTRACT}

This article presents the evidence for Early Archaic ritual activity on the site of a Late Bronze Age cemetery a short distance outside the walls of Troy, at a spot known to excavators as "A Place of Burning." Here, as at the West Sanctuary adjacent to the citadel, the evidence follows a pattern similar to that found in hero and ancestor cults at other sites. Growing population in the region may have led the inhabitants of Troy to use associations with Bronze Age remains as a way of strengthening territorial claims and bolstering the power of the local elite.

\section{INTRODUCTION}

In 1932, on a gentle slope northwest of the Trojan citadel, Carl Blegen and a team of excavators from the University of Cincinnati found what they interpreted as evidence of cremations conducted at the site during the Late Bronze Age and Archaic period. ${ }^{1}$ Since then this spot, which they named "A Place of Burning," has attracted little scholarly attention. ${ }^{2}$ In 2003-2005 a team from the University of Tübingen resumed excavation at the site, and analysis of the new finds suggests a somewhat different conclusion. A large number of vessel fragments probably do belong to Late Bronze Age (LBA) cremation urns, and thus support part of Blegen's original interpretation. The Early Archaic material, however, can be better understood as

Diane Thumm-Doğrayan. John Wallrodt graciously helped prepare the illustrations, for which I am very grateful. I thank especially Brian Rose and Ernst Pernicka for permission to study the material. I have also benefited greatly from the suggestions of the anonymous reviewers. All dates are в.с.

\footnotetext{
2. Huxley (1966, p. 157) has suggested that the Lokrian maidens were cremated at the Place of Burning; more recently, Fisher (2000, pp. 60-61) and Hertel (2008b, pp. 113-124) have proposed that it was a cult area.
}

(C) The American School of Classical Studies at Athens 
the remains of feasting that took place in or around a building deliberately set within the Late Bronze Age cemetery.

Nearby, in the West Sanctuary, a cult building had been erected in the 9 th to mid-8th century on a site specifically chosen to draw attention to structures of the Late Bronze Age. Behind the cult building, rituals were performed around stone circles set high on a platform prominently located next to the LBA citadel wall. In addition, Maureen Basedow has recently presented evidence for later activity around Bronze Age ruins in the South Gate area. ${ }^{3}$

The evidence from Troy fits into a wider pattern observed in the 8th-7th centuries in other regions, such as Attica and the Argolid, where a variety of practices, including tomb cult, hero shrines, and the location of cult buildings near LBA ruins, indicate a desire by inhabitants to claim or forge a connection with the Late Bronze Age. At Troy, the intensification of ritual activity around LBA remains is probably related to a rise in population, and perhaps to the interest of outside groups in establishing colonies or territorial control of the Troad, in the late 8th and first half of the 7 th century.

\section{EXCAVATION HISTORY, ARCHITECTURE, AND STRATIGRAPHY}

The Place of Burning is located 80-90 m northwest of the Late Bronze Age citadel of Troy, in sector vw3 (Fig. 1). Marion Rawson supervised the excavations at the site in 1932, during the first season of work by Carl Blegen's team. ${ }^{4}$ The excavators opened a series of long, narrow trenches while searching for a cemetery, and with the exception of one building, found that the area was not generally inhabited during the Archaic period. Later city planners likewise left it outside the protection of the Hellenistic city wall, and burials dotted the slopes in the Hellenistic and Roman periods, as seems to have been the case in the Late Bronze Age as well. ${ }^{5}$ For reasons probably related to the sloping terrain, it was never favored for habitation.

In one of the narrow trenches, which was later enlarged, Rawson found a structure consisting of a curving wall encircling a deposit of burned debris, ceramics, and animal and human bones (Fig. 2). In the final reports of the University of Cincinnati excavations, Blegen describes the stratigraphy and architecture, with a brief discussion of some of the pottery. ${ }^{6}$ There were many gray ware cups, amphoras, dinoi, and kraters from the Troy VIII (Archaic) period, as well as fragments of large urns, similar to those found in the Troy VI (LBA) cemetery south of the citadel. The presence of cinerary urns, burned debris, and human bones led Blegen to the conclusion that this was a site of cremations in both the Late Bronze Age and the Archaic period.

From 2003 to 2005, a team from the University of Tübingen conducted renewed excavations in sector vw3. Excavator Ralf Becks uncovered more of

3. Basedow 2009, pp. 136-142.

4. Rawson excavation notebook 1932, vol. 1, area 7 in trench M6,

Troy excavation records, Department of Classics, University of Cincinnati (hereafter, Rawson notebook). 5. In her notebook Rawson records burials of the Hellenistic or Roman period in several of the trenches. See also Blegen 1932, pp. 443-444.

6. Troy III, pp. 394-396, figs. 285287; Troy IV, p. 299. 


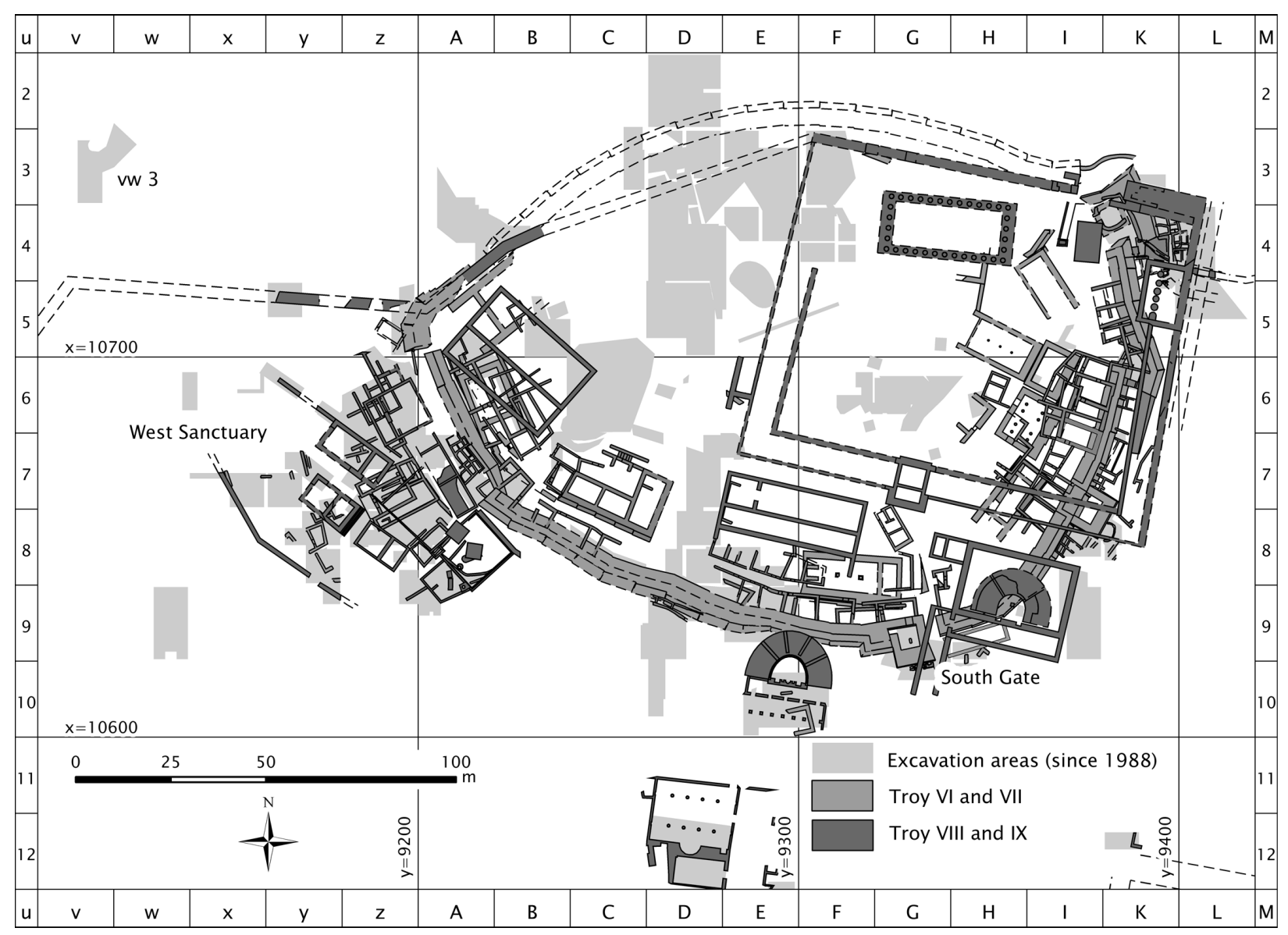

Figure 1. Plan of Troy. Courtesy the Troia Project

7. Korfmann 2004, pp. 12-13; 2005, pp. 9-10; Jablonka 2006, p. 9, figs. 8, 9; Becks excavation notebooks 2003, 2004, 2005, sector vw3, Troia Project, University of Tübingen (hereafter, Becks notebooks). Preliminary publications reported slightly larger dimensions for the oval building, but these have been corrected.

8. Rawson notebook 1932, p. 88. 287. the structure discovered by Rawson, another wall to the south, and several exterior pits (Figs. 3, 4). ${ }^{7}$ By piecing together the information from both excavations, the following architectural and stratigraphic sequence can be reconstructed.

The uppermost stratum contained Late Hellenistic and Roman graves. Below this were the remains of the building, which appears to have been roughly oval in shape, $9.71 \times 5.35 \mathrm{~m}$, with an entrance $1 \mathrm{~m}$ wide on the short southwest side; a pivot stone for the door was found in place. Parts of both ends of the building survive, but a large section in the middle does not. Of the west end, excavated by Becks, only a small portion consisting of a single course of stones is preserved, and because so little remains, there is some doubt about the oval plan. The east end, excavated by Rawson, was more complete, with stone foundations standing to a height of ca. $1 \mathrm{~m}$. Blegen described the wall as "battered" because of its distinct inward inclination.

When Rawson excavated within the building, she found animal bones, human bone fragments, burned wood and other carbonized material, and a mixture of ceramics dating to the Late Bronze Age and Archaic period. A large number of stones were also found in the building, some of them in heaps. In her notebook, Rawson records a possible hearth, but this feature was not included in the published reports. ${ }^{8}$ No distinct floor level could be identified. Blegen briefly mentions another poorly preserved wall, which may have been a crosswall within the building. ${ }^{9}$ 


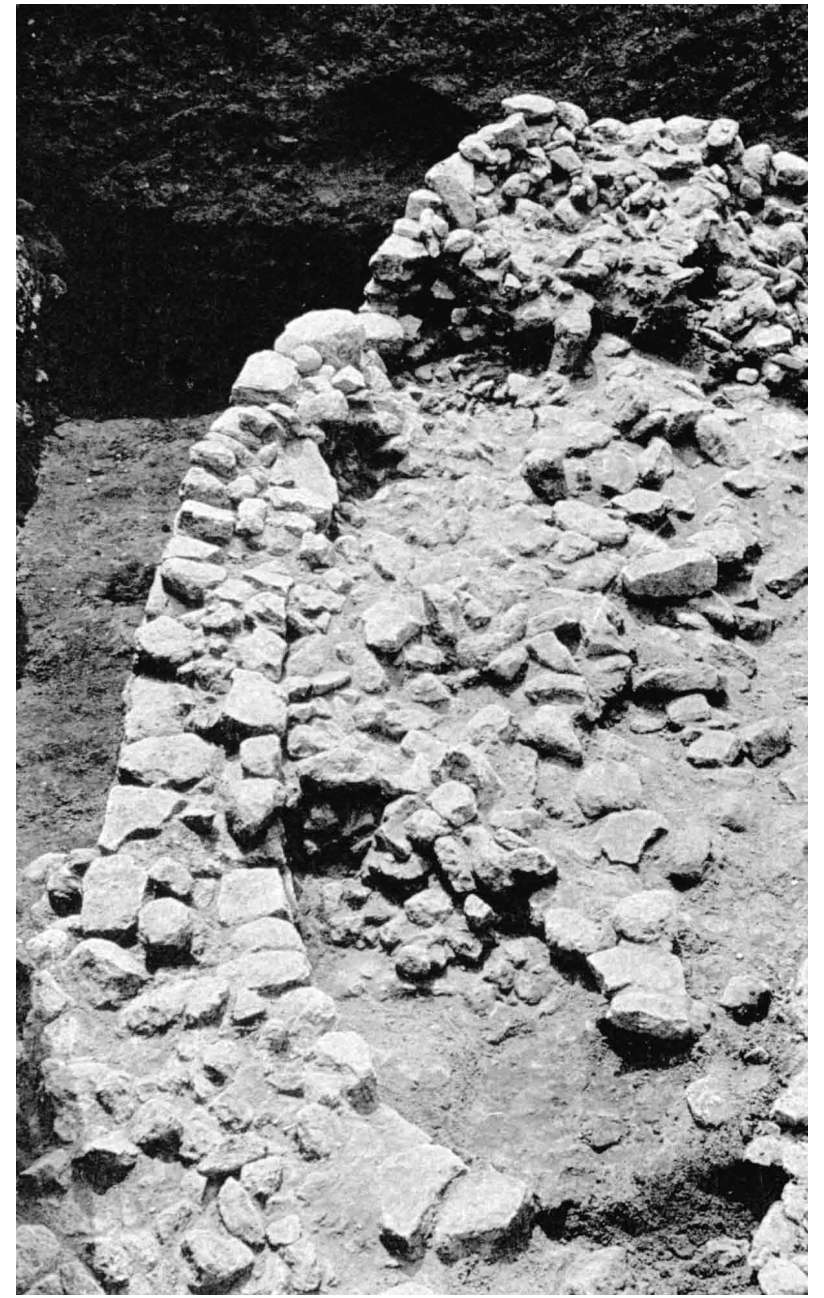

Below the foundation level of the oval structure, Rawson encountered a LBA (Troy VI) stratum, a small portion of which was excavated down to bedrock. At this point, however, water began to seep into the trench and excavation ceased. ${ }^{10}$ The excavators within the building in 2003 removed quantities of eroded fill until they finally reached Troy VI levels. No clear Archaic strata or floor level could be distinguished from the accumulated fill. Since the water table in the area is now lower as a result of pumping for agricultural irrigation, it was possible to excavate the Troy VI levels without water filling the trench. In the lowest levels over bedrock, Early and Middle Bronze Age ceramics were found. ${ }^{11}$

In 2004 and 2005, Becks also investigated the area outside the building, where he discovered several pits: two large ones, ca. $1 \mathrm{~m}$ wide and $0.75-0.80 \mathrm{~m}$ deep, and four small circular ones, ca. $0.40 \mathrm{~m}$ in diameter, which were set in a row close together and probably once held wooden posts (Figs. 3,4$)$. The line of postholes may originally have extended farther to the east along the side of the building; Becks observed possible traces of additional postholes, but these were not clearly preserved..$^{12}$ If the posts did continue, they may have formed a kind of peristyle, with the section in front of the building serving as a porch. ${ }^{13}$ Alternatively, they may have formed part of an additional barrier or enclosure near the entrance to the
Figure 2. Oval structure excavated in 1932 at the Place of Burning (sector vw3). Troy III, fig. 285. Courtesy Department of Classics, University of Cincinnati

10. Rawson notebook 1932, p. 99; Troy III, pp. 394-396; Troy IV, p. 299.

11. Korfmann 2004, pp. 12-13. Blegen (1932, p. 441) also mentions finding early prehistoric ceramics in this area.

12. R. Becks (pers. comm.).

13. Cf. the evidence for peristyles around Late Geometric-Early Archaic oval buildings at Oropos (Mazarakis Ainian 1998, pp. 193-194, 201-202). 
Figure 3. Plan of the excavation of 2003-2005 in sector vw3, showing the oval structure, pits, and terrace wall. Courtesy the Troia Project

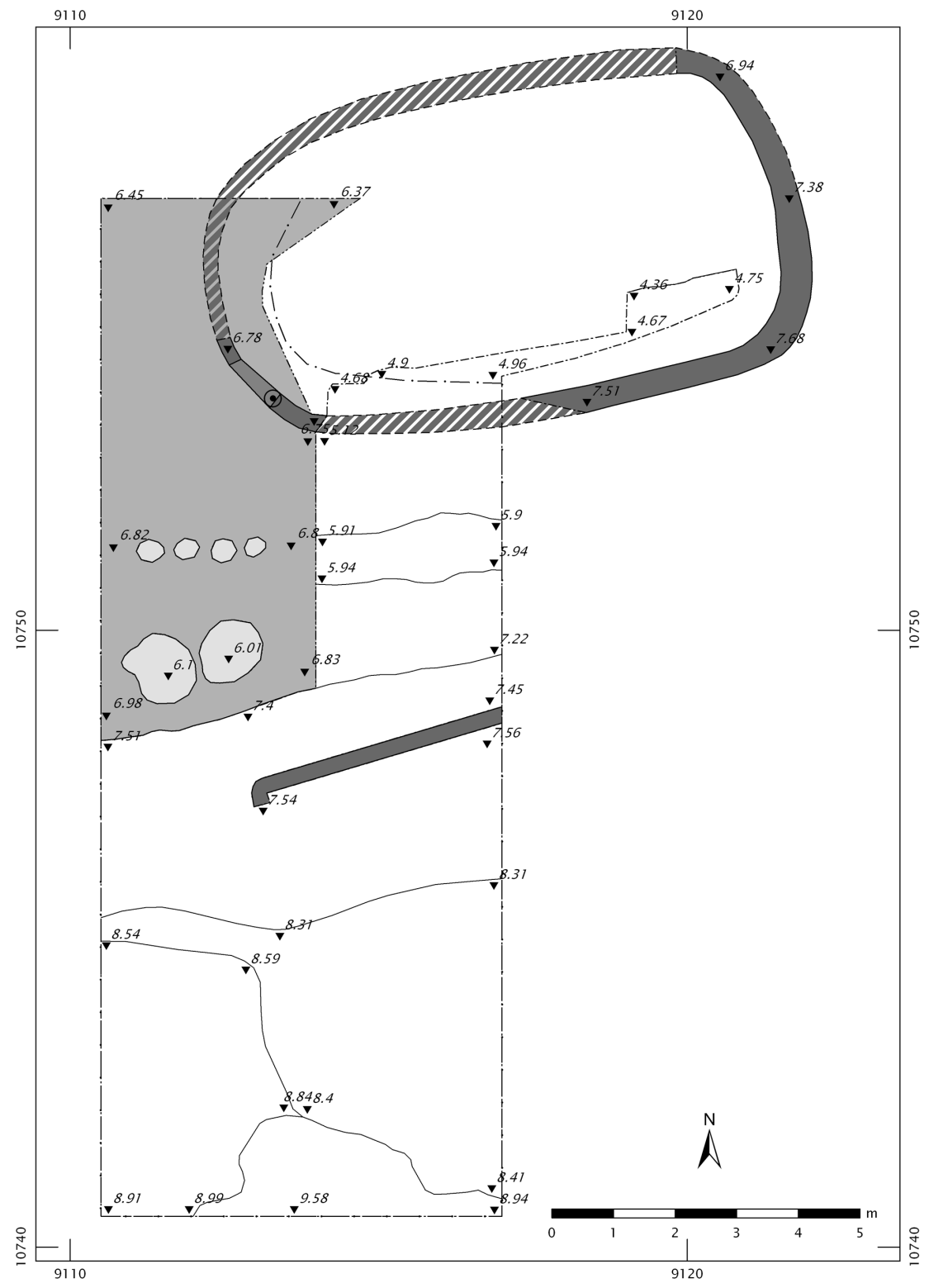

building, or even part of another structure. Farther south were the remains of another thin wall, $0.30 \mathrm{~m}$ wide and poorly preserved, which Becks interprets as a terrace wall. ${ }^{14}$

The wall of the oval structure varied from 0.30 to $0.50 \mathrm{~m}$ in thickness. Blegen felt that this was too thin to support a superstructure; instead, he interpreted it as a terrace wall supporting a precinct. ${ }^{15}$ Iron Age structures, however, can have quite thin walls, ${ }^{16}$ and if the pivot stone at the west end is in situ, it would support the interpretation of the structure as a roofed building, against Blegen's suggestion of a terrace. It nevertheless remains possible that the structure was an open enclosure.

14. Becks notebooks 2004, 2005;

Korfmann 2005, pp. 9-10; Jablonka 2006, p. 9, figs. 8,9 .

15. Troy III, pp. 394-396, figs. 285287; Troy IV, p. 299.
16. Fagerström (1988, pp. 119-121) observes that Iron Age walls are usually $0.50-0.70 \mathrm{~m}$ thick; walls as thin as $0.30 \mathrm{~m}$ do occur, but infrequently. 


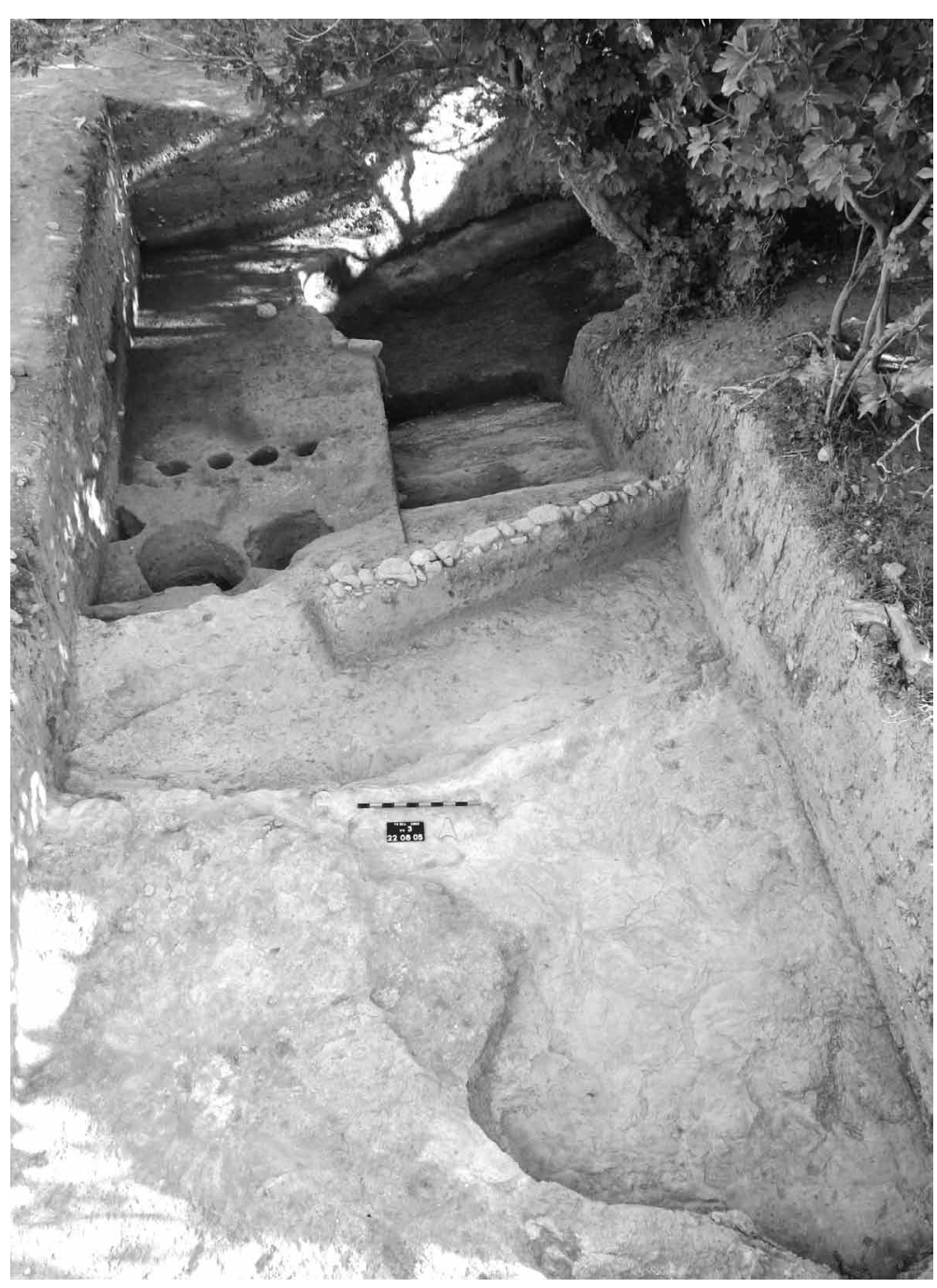

Blegen reports that human bones were discovered in the structure, along with considerable quantities of animal bones. ${ }^{17}$ In the excavation notebook, Rawson writes that human bones were found throughout the excavated strata, but the final reports do not mention human bones in the lowest Troy VI level. Human bones were identified in three of the units excavated in 2003-2005, two from deep levels below the building and one from a large pit outside the building. ${ }^{18}$ Admittedly, these are fewer than one would expect, in view of Blegen's interpretation of the area as a place for cremations. It is possible that the cremated bone material is very fragmented and therefore hard to detect, as seems to have been the case in the Troy VI cremation urn cemetery also excavated by Blegen. ${ }^{19}$ The animal bones have not yet been studied. p. 299.

17. Troy III, pp. 394-396; Troy IV,

18. Only eight of the excavated units with bone material were checked for human bone. I thank Henrike Kiesewetter, who studied the human bones, for the following information. Behälter (Beh.) 22 contained a human fibula, two human femur fragments, and two rib fragments that might be human or porcine; Beh. 29 contained a fragment of a human femur. Both units
Figure 4. View of the excavation of 2003-2005 in sector vw3, showing the west end of the oval structure, pits, and terrace wall, from the south. Photo courtesy the Troia Project

are from Troy VI levels within the building but below the base of the walls. Beh. 274, from one of the large pits, contained a human finger bone.

19. Troy III, pp. 370-391. 


\section{TABLE 1. QUANTITIES OF RIM SHERDS FROM MIXED LATE BRONZE AGE AND EARLY ARCHAIC CONTEXTS}

\begin{tabular}{lc}
\hline Ware and Shape & No. of Rims \\
\hline G2/3 ware cups (Early Archaic) & 13 \\
G2/3 ware jugs (Early Archaic) & 4 \\
Mycenaean painted fine wares (LBA) & 2 \\
Various painted and banded vessels (Early Archaic) & 11 \\
Gray ware cups (LBA and Early Archaic) & 63 \\
Gray ware bowls (LBA and Early Archaic) & 31 \\
Gray ware jugs (LBA and Early Archaic) & 13 \\
Gray ware table amphoras (LBA and Early Archaic) & 24 \\
Gray ware kraters/small jars (LBA and Early Archaic) & 24 \\
Gray ware large jars (LBA and Early Archaic) & 7 \\
Gray ware large bowls or basins (LBA and Early Archaic) & 4 \\
Gray ware uncertain shape (LBA and Early Archaic) & 6 \\
Tan ware cups (probably LBA) & 4 \\
Tan ware bowls (probably LBA) & 7 \\
Tan ware closed vessels (probably LBA) & 2 \\
Tan ware uncertain shape (probably LBA) & 1 \\
Cooking pots (probably Early Archaic) & 16 \\
Gritty ware jars (probably LBA) & 48 \\
Plain ware jars (LBA and Early Archaic) & 19 \\
Plain ware jugs (LBA and Early Archaic) & 5 \\
Plain ware bowls (LBA and Early Archaic) & 4 \\
Plain ware uncertain shape (LBA and Early Archaic) & 5 \\
Pithoi (probably LBA) & 2 \\
Earlier wares (Early or Middle Bronze Age) & 18 \\
Uncertain pieces & 5 \\
\hline
\end{tabular}

The totals reflect combined counts of rim sherds in the following units: sector vw3, Beh. 239, 241, 263, 269, 273, 277, 281, 284, 286, 289, 292, 298, 301, 305, 308, 311, 314, 320, $322,325,328,331,337,344,347$.

\section{POTTERY AND OTHER FINDS FROM THE 2003-2005 EXCAVATIONS}

The excavations by the University of Tübingen concentrated mostly on the area outside the building, where large quantities of Early Archaic (700-650) and Late Bronze Age (late Troy VI) ceramics were found mixed together in the same contexts. The numbers of rim sherds found in these mixed contexts are presented in Table 1 . The trench was excavated in many different units, but study showed no apparent differences in quantity, type, or preservation among the ceramic material found in the pits, that found directly outside the building, and that found farther away. One exception is a small area outside the building and directly above the bedrock, which contained primarily Troy VI pottery. ${ }^{20}$ Deep Troy VI layers were also encountered below the building. ${ }^{21}$ The numbers of rim sherds found in these pure LBA levels are presented in Table 2, separately from those found in the mixed contexts. ${ }^{22}$ 
TABLE 2. QUANTITIES OF RIM SHERDS FROM LATE BRONZE AGE CONTEXTS

\begin{tabular}{lc}
\hline Ware and Shape & No. of Rims \\
\hline Mycenaean painted fine ware & present \\
Gray ware cups & 16 \\
Gray ware bowls & 14 \\
Gray ware jugs & 3 \\
Gray ware table amphoras & 2 \\
Gray ware kraters/jars & 5 \\
Gray ware large jars & 6 \\
Gray ware large bowls or basins & 2 \\
Gray ware uncertain shape & 4 \\
Tan ware bowls & 7 \\
Handmade coarse ware & 1 \\
Plain ware jars & 2 \\
Plain ware jugs & 1 \\
Plain ware uncertain shape & 8 \\
Gritty ware large jars & 22 \\
Possible Early and Middle Bronze Age wares & 4 \\
\hline
\end{tabular}

The totals reflect combined counts of rim sherds in the following units: sector vw3, Beh. 25, 28, 350, 353, 356.

\section{Catalogue}

\section{G2/3 WARE}

1 Kantharos rim $^{23}$

Figs. 5, 6

Sector vw3.273:7. Est. Diam. 0.132 m. A quarter of the rim preserved. Fabric pink/orange (2.5YR 6/6), fine. Exterior decorated with two rows of small dots between two horizontal bands. Groove on exterior under band of decoration. Paint uneven, dark brown or orange, on tan ground (5YR 6/4). Interior has streaky brown/orange paint.

Early Archaic.

2 Kantharos rim

Figs. 5, 6

Sector vw3.292:3. Est. Diam. 0.13 m. An eighth of the rim preserved. Fabric light pink/orange (2.5YR 6/6), fine. Exterior has a band of linked $V_{s}$ along the top of the rim. Red/orange paint (10R 5/6) on pink/orange ground (2.5YR 6/6). Interior has red/orange paint.

Early Archaic.

3 Kantharos rim

Figs. 5, 6

Sector vw3.273:9. Est. Diam. $0.10 \mathrm{~m}$. A quarter of the rim preserved. Broken near the handle. Fabric pink/orange (2.5YR 6/6), fine. Rim has a thin brown band (5YR 3/2) along the top. Ridge on exterior is marked with three horizontal bands. Tan/pink ground (5YR 7/4). Interior has streaky red/brown paint.

Early Archaic.

4 Kantharos rim

Figs. 5, 6

Sector vw3.286:3. Est. Diam. $0.122 \mathrm{~m}$. An eighth of the rim preserved. Fabric pink/orange (2.5YR 6/6), fine. Step pattern along the rim. Thin horizontal band
23. In the catalogue, sherds are identified by sector designation (vw3) and Behälter number, followed by a colon and the individual sherd number. Fabric and paint colors are described using the 2000 edition of the Munsell Soil Color Charts (New Windsor, N.Y.). Blegen shape numbers are those used in Troy III. All sherds are currently stored in the Troy depots. 

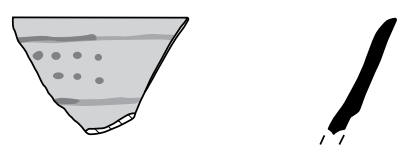

1

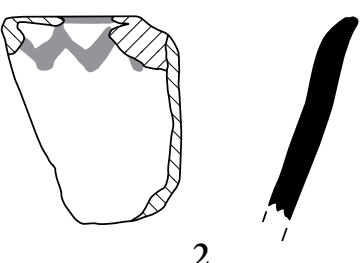

2
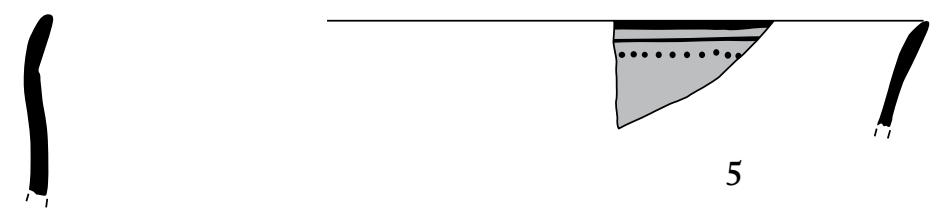

5

4

Figure 5. G2/3 ware kantharoi 1-5. Scale 1:2. Drawings M. Möck-Aksoy directly below a faintly incised groove on exterior. Brown paint (10R 4/4) on pink/ orange ground (2.5YR 6/6). Streaky brown paint on interior.

Early Archaic.

5 Kantharos rim

Figs. 5, 6

Sector vw3.269:5. Est. Diam. $0.12 \mathrm{~m}$. An eighth of the rim preserved. Fabric pink/orange (2.5YR 6/6), fine. Exterior has a row of small dots under a thin horizontal band. Dark brown paint (10R 2.5/1) on tan ground (10R 7/4). Dark brown paint on interior.

Early Archaic.

6 Kantharos handle

Fig. 6

Sector vw3.273:2. Width $0.028 \mathrm{~m}$. Handle joined at the rim. Fabric pink/ orange $(2.5 \mathrm{YR} 6 / 6)$, fine. Dark brown band at the rim $(2.5 \mathrm{YR} 3 / 1)$; $\mathrm{X}$ in dark brown paint on the handle. Tan/pink ground (5YR 7/4).

Early Archaic.

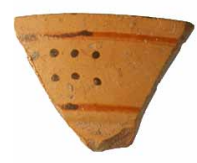

1

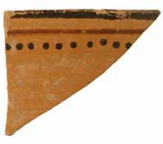

5

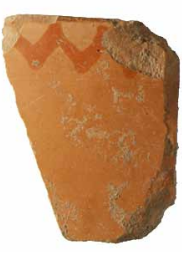

2

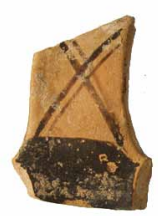

6

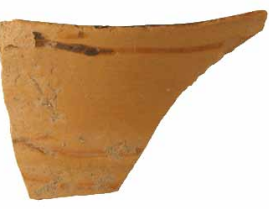

3

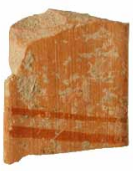

7

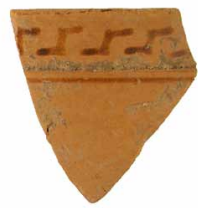

4

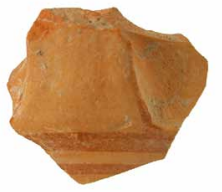

8

Figure 6. G2/3 ware kantharoi 1-8. Scale 1:2. Photos G. Bieg 


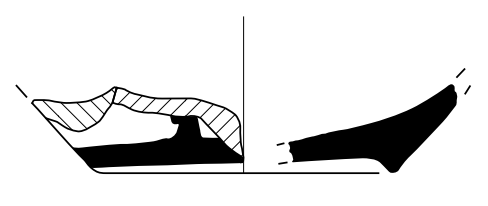

9

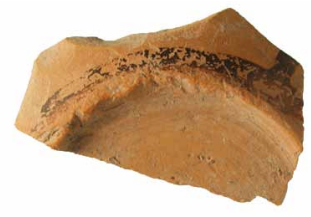

7 Kantharos handle

Fig. 6

Sector vw3.239:2. Max. p. dim. 0.027 m. Fabric pink/orange (2.5YR 6/6), fine. Two horizontal red/orange bands (10R 5/6) on pink/orange ground (2.5YR 6/6). Early Archaic.

8 Kantharos handle

Fig. 6

Sector vw3.311:6. Max. p. dim. 0.037 m. Fabric dark pink/orange (2.5YR 6/6), fine. Two red bands on exterior where the handle joins the body. Tan ground (5YR 6/4). Red paint (10R 4/6) on interior.

Early Archaic.

9 Cup base

Fig. 7

Sector vw3.273:3. Est. Diam. 0.06 m. A quarter of the base preserved. Ring base is slightly pointed. Fabric pink/orange (2.5YR 6/6), fine. Dark brown horizontal band around the foot joins to a vertical band on the body. Dark brown paint (2.5YR 3/2) on light brown ground (2.5YR 6/4). Interior has streaky brown paint.

Early Archaic.

10 Cup base

Fig. 7

Sector vw3.273:40. Est. Diam. 0.07 m. A quarter of the base preserved. Pointed ring base. Fabric pink/orange (2.5YR 6/6), fine. Dark brown band (2.5YR 3/3) around exterior of base. Light brown ground (2.5YR 6/4). Streaky brown/orange paint on interior.

Early Archaic.

11 Jug rim and shoulder

Fig. 8

Sector vw3.347:1. Diam. rim $0.073 \mathrm{~m}$. Rim and part of body preserved. Eleven joining pieces. Fabric pink/orange (2.5YR 6/6), fine. Exterior has two narrow bands along the rim and a wide band on the neck. Slight ridge where the neck joins the shoulder. Brown band along the upper part of the interior of the rim. Brown paint (10R 4/4) on pink/orange ground (2.5YR 6/6).

Early Archaic.

12 Jug neck fragment Fig. 8

Sector vw3.322:6. Max. p. dim. 0.039 m. Fabric pink/orange (2.5YR 6/6), fine. Exterior has a band of linked $\bigvee$ s. Brown paint (10R 3/4) on tan/pink ground (10R 7/4). Interior has a brown band along the rim.

Early Archaic.

13 Jug rim

Fig. 8

Sector vw3.286:1. Est. Diam. 0.09 m. An eighth of the rim preserved. Small ledge rim. Fabric pink/orange (2.5YR 6/6), fine. Interior and exterior have brown paint (10R 4/4).

Early Archaic.
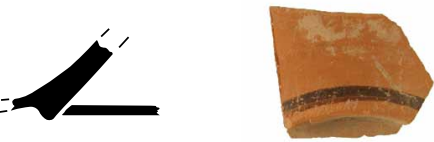

10

Figure 7. G2/3 ware cups 9, 10 .

Scale 1:2. Photos G. Bieg; drawings M. Möck-Aksoy 

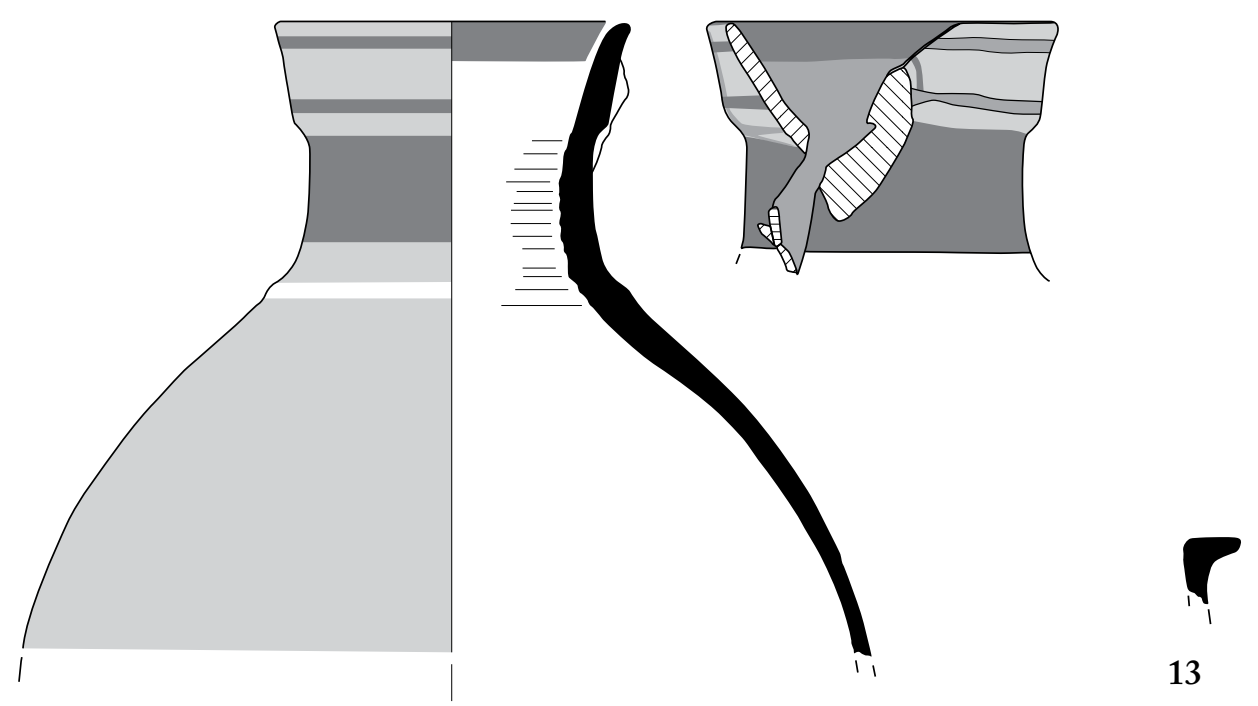

11

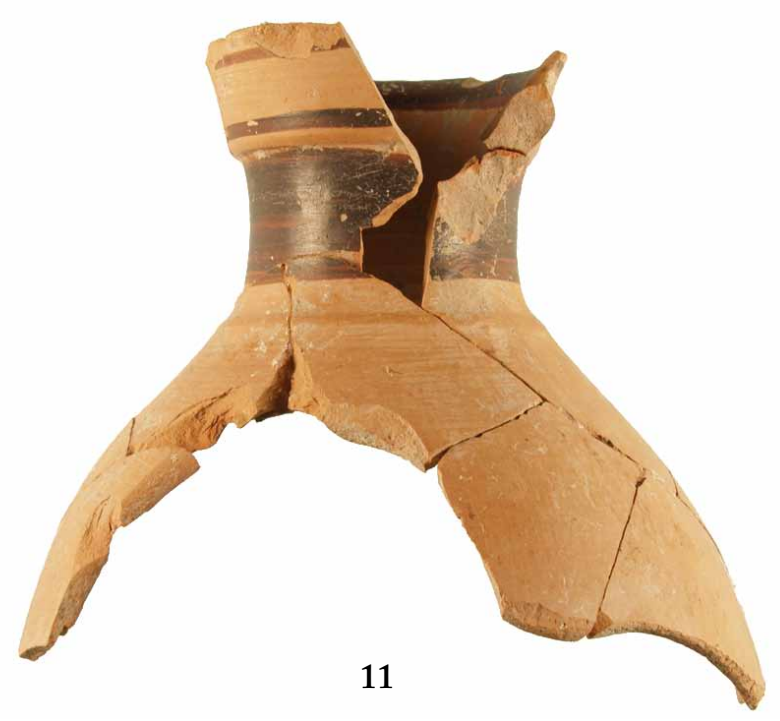

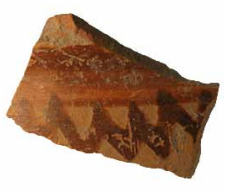

12

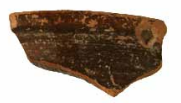

13
Figure 8. G2/3 ware jugs 11-13. Scale 1:2. Photos G. Bieg; drawings M. Möck-Aksoy
14 Krater body fragment

Fig. 10

Sector vw3.277:5. Max. p. dim. 0.047 m. Fabric pink/orange (2.5YR 6/6), fine. Raised ridge above a groove on exterior. Exterior has a pattern of two vertical lines between two horizontal rectangles, perhaps part of a meander. Brown paint (5YR 3/2) on tan ground (5YR 6/4). Interior has brown paint.

Early Archaic.

\section{Various Painted Wares}

15 Kantharos rim

Figs. 9, 10

Sector vw3.269:6. Est. Diam. 0.13 m. An eighth of the rim preserved. Fabric light brown (10R 5/4), fine. Exterior has a horizontal band in dark brown paint (10R 3/2) on tan ground (10R 6/4). Interior has dark brown paint with two lighter reserved bands near the rim. Similar to G2/3 ware, but of different fabric.

Early Archaic. 


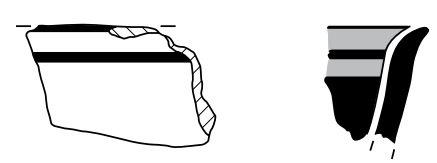

15

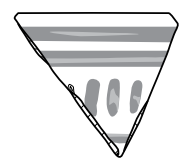

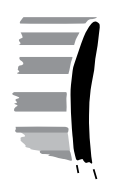

16

\section{I}

18

16 Cup rim

Figs. 9, 10

Sector vw3.344:2. Est. Diam. 0.16 m. A sixteenth of the rim preserved. Fabric brown/orange (5YR 5/6), no visible inclusions. Exterior has two bands along the rim; below is a row of vertical dashes followed by another horizontal band. Brown paint (10R 3/3) on cream-colored ground (5YR 8/2). Interior is banded.

Cf. Samos V, p. 87, no. 155, pl. 30, kantharos or bowl, before 660.

\section{Cup rim}

Figs. 9, 10

Sector vw3.322:4. Est. Diam. 0.134 m. A sixteenth of the rim preserved. Fabric light tan/gray (10YR 7/2), fine. Exterior has a dark brown band (10YR $3 / 2$ ) along the rim. Parts of two vertical dashes are preserved. Interior has a worn brown/black band along the upper part of the rim. Cream-colored ground (10YR 8/2). Probably imported.

Probably Early Archaic.

Figs. 9, 10

Sector vw3.263:7. Est. Diam. 0.166 m. A sixteenth of the rim preserved. Fabric $\tan (10 Y R$ 7/4), fine. Exterior and interior have red/brown matte paint (10R 4/4) except for a reserved band and a groove along the rim. Imported.

Probably Early Archaic.

19 Jug rim

Figs. 9, 10

Sector vw3.273:41. Est. Diam. interior neck $0.046 \mathrm{~m}$. Half of rim and neck preserved. Slightly flaring rim. Spout is broken. Fabric brown (2.5YR 5/4), fine. Exterior is covered with matte dark brown paint (2.5YR 3/1). Interior is unpainted except for an uneven band along the upper rim. Probably imported.

Probably Early Archaic.

20 Amphora body fragment

Fig. 10

Sector vw3.322:2. Max. p. dim. 0.043 m. Fabric light brown (5YR 5/4) with somewhat coarse black, brown, and white inclusions, gold and silver mica. Exterior has part of four concentric circles. Brown paint (10R 3/1) on tan ground (10R 7/2).

Troy Protogeometric Group II (Catling 1998, pp. 166-170). PG Group II amphoras occur at Troy in contexts of the 8 th to mid-7th century.

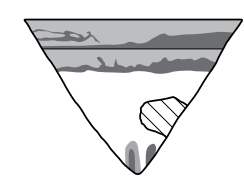

17

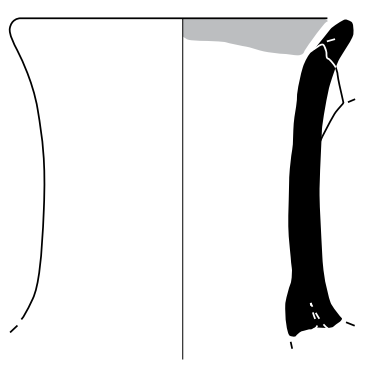

19

Figure 9. Various painted wares

15-19. Scale 1:2. Drawings M. Möck-

Aksoy 


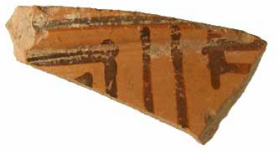

14

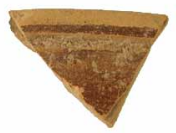

18

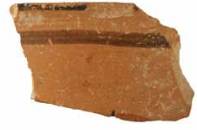

15

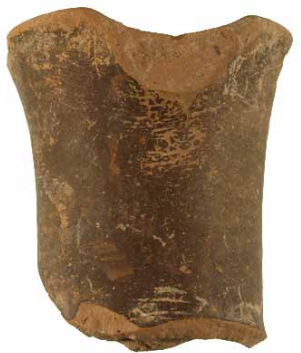

19

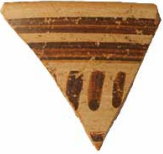

16

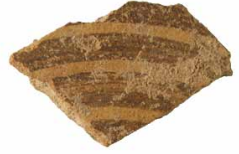

20

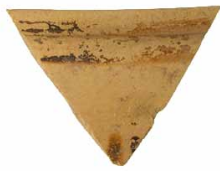

17

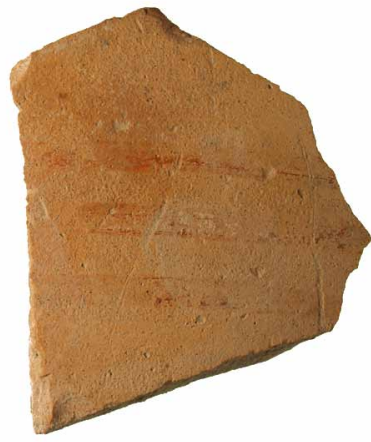

21

painted wares 15-21. Scale 1:2. Photos G. Bieg

21 Amphora body fragment

Fig. 10

Sector vw3.289:3. Max. p. dim. 0.087 m. Fabric light brown at core (2.5YR 6/4) with pink/orange edges (2.5YR 6/6), white and gray inclusions, gold and silver mica. Three horizontal bands in very worn red paint (10R 4/8) on tan ground (10R 7/4).

Does not fit exactly into known Troy Protogeometric groups; probably related to Troy PG Group II (cf. 20).

Gray Ware

22 Stemmed cup base

Fig. 11

Sector vw3.263:9. Est. Diam. 0.10 m. A quarter of the base preserved. Fabric gray/brown (10R 5/1) with white inclusions. Exterior burnished gray (Gley $14 / \mathrm{N})$. Blegen shape A51 or A100.

Late Bronze Age.

23 Stemmed cup base

Fig. 11

Sector vw3.28:64. Diam. 0.09 m. Half of the base preserved. Fabric gray/ brown $(2.5 \mathrm{YR} 5 / 1)$ with a few white inclusions. Interior and exterior burnished light gray/brown (2.5YR 6/1). Blegen shape A51 or A100.

Late Bronze Age.

24 Cup rim

Fig. 11

Sector vw3.28:1. Est. Diam. 0.21 m. An eighth of the rim and handle preserved. Round horizontal handle. Fabric gray (Gley $16 / \mathrm{N}$ ) with a few white inclusions, mica. Interior and exterior burnished gray (Gley $15 / \mathrm{N})$. Blegen shape A93.

Late Bronze Age.

25 Carinated cup rim

Fig. 11

Sector vw3.322:7. Est. Diam. 0.17 m. An eighth of the rim preserved. Slightly flaring rim, carinated at shoulder. Fabric gray (Gley $15 / \mathrm{N}$ ), a few small 


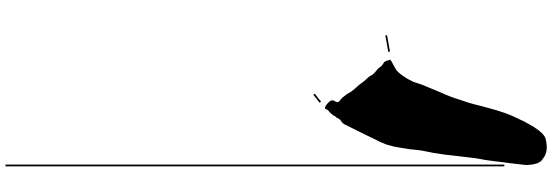

22
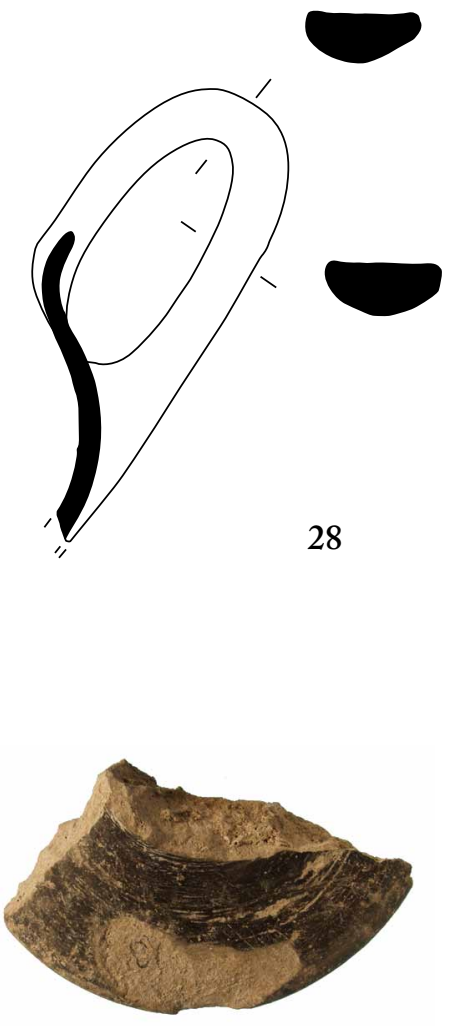

22

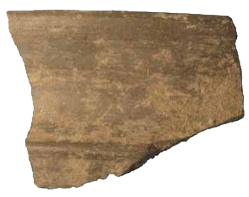

25

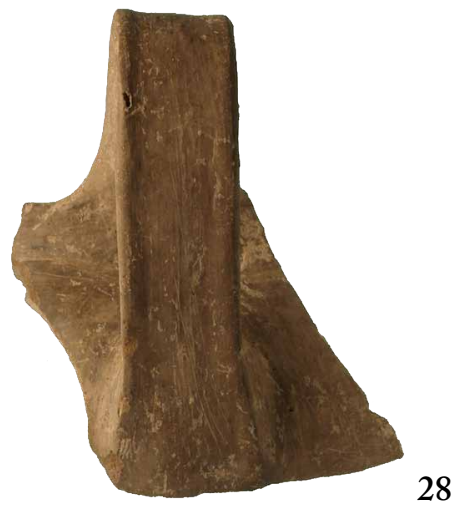

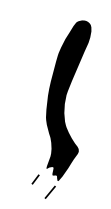

25

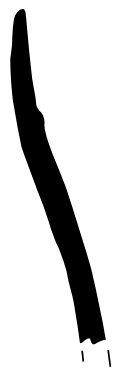

29

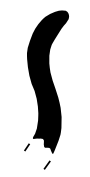

26

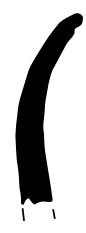

30

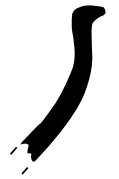

27

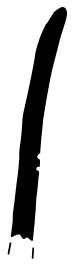

31

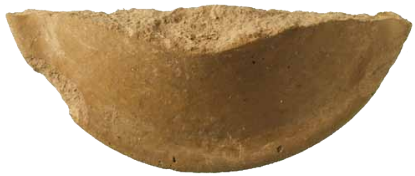

23

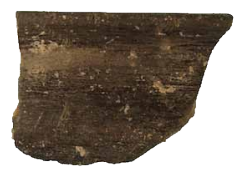

26

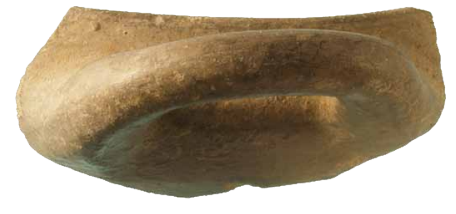

24

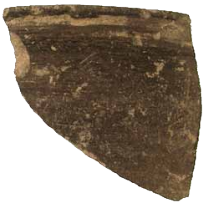

27

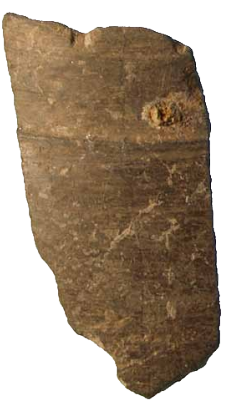

29

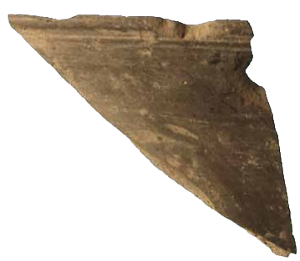

30

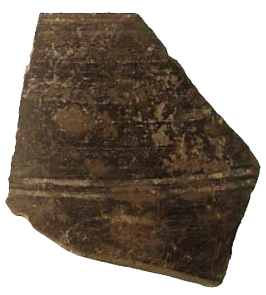

31 
Figure 11 (opposite). Gray ware cups 22-27 and kantharoi 28-31. Scale 1:2. Photos G. Bieg; drawings M. Möck-Aksoy white inclusions. Interior and exterior burnished gray (Gley $15 / \mathrm{N})$. Blegen shape A94.

Late Bronze Age.

26 Large shallow cup or bowl rim

Fig. 11

Sector vw3.311:3. Est. Diam. 0.19 m. A sixteenth of the rim preserved. $\mathrm{S}$-shaped profile. Fabric brown (7.5YR 5/3) with gray edges, no visible inclusions. Interior and exterior burnished gray (Gley $14 / \mathrm{N})$.

Late Bronze Age or Early Archaic.

27 Cup rim

Fig. 11

Sector vw3.311:5. Est. Diam. 0.13 m. An eighth of the rim preserved. S-shaped profile. Fabric gray (Gley $14 / \mathrm{N})$ with some small white inclusions. Interior and exterior burnished gray (Gley $14 / \mathrm{N})$.

Late Bronze Age or Early Archaic.

28 Kantharos rim and handle

Fig. 11

Sector vw3.286:13. W. 0.07 m. An eighth of the rim and handle preserved. High strap handle. Rounded profile with no carination. Fabric gray (Gley $16 / \mathrm{N}$ ) with brown edges, white inclusions. Exterior burnished gray (Gley $15 / \mathrm{N})$; interior smoothed but unburnished.

Early Archaic.

29 Kantharos rim

Fig. 11

Sector vw3.273:21. Est. Diam. 0.15 m. A quarter of the rim preserved. Deep cup. Ridge on exterior. Remains of a lead repair join. Fabric gray/brown (10R 4/1), fine. Exterior burnished gray (Gley $14 / \mathrm{N})$; interior smoothed but unburnished.

Early Archaic.

30 Kantharos rim

Fig. 11

Sector vw3.292:4. Est. Diam. $0.135 \mathrm{~m}$. An eighth of the rim preserved. Exterior has two faint incised lines along the rim. Fabric gray (Gley $15 / \mathrm{N}$ ), fine. Interior and exterior burnished gray (Gley $14 / \mathrm{N})$.

Early Archaic.

31 Kantharos rim

Fig. 11

Sector vw3.311:2. Est. Diam. 0.13 m. Less than a sixteenth of the rim preserved. Straight-sided cup. Two incised lines on exterior. Fabric gray/brown at core (10R 5/1) with lighter gray/brown edges, white inclusions. Interior and exterior burnished dark gray (Gley $13 / \mathrm{N})$.

Early Archaic.

32 Bowl rim

Fig. 12

Sector vw3.322:13. Est. Diam. $0.21 \mathrm{~m}$. An eighth of the rim preserved. Rounded rim. Fabric gray (Gley $15 / \mathrm{N}$ ), fine. Burnished gray.

Late Bronze Age or Early Archaic.

33 Bowl/dish rim

Fig. 12

Sector vw3.273:15. Est. Diam. 0.30 m. A sixteenth of the rim preserved. Two joining fragments. Flat rim. Fabric gray (Gley $14 / \mathrm{N})$, compact, with only a few white inclusions. Interior and exterior burnished gray (Gley $14 / \mathrm{N})$.

Late Bronze Age or Early Archaic. 


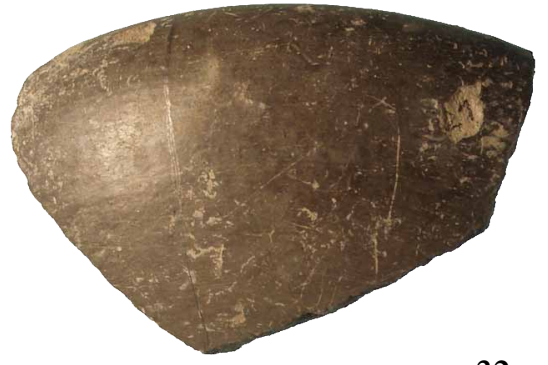

32

34 Table amphora rim

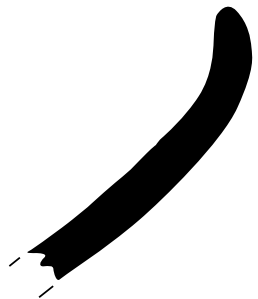

Sector vw3.273:23. Est. Diam. 0.14 m. A sixth of the rim preserved. Two joining fragments. Thickened oval lip. Incised line where the rim joins the neck. Fabric brown at core (10R 4/4), with gray/brown edges, a few white inclusions, slight traces of mica. Interior and exterior burnished gray (Gley $14 / \mathrm{N})$.

Probably Early Archaic.

35 Table amphora rim

Fig. 13

Sector vw3.322:11. Est. Diam. $0.16 \mathrm{~m}$. A sixteenth of the rim preserved. Rounded rim. Fabric gray (Gley $15 / \mathrm{N}$ ) with a few white inclusions. Exterior burnished gray (Gley $15 / \mathrm{N})$; interior unburnished.

Probably Early Archaic.

36 Jar rim

Fig. 13

Sector vw3.277:3. Est. Diam. $0.20 \mathrm{~m}$. A sixteenth of the rim preserved. Rim flat on top. Incised ridge on exterior under the rim. Fabric gray (Gley 1 $4 / \mathrm{N})$, fairly fine, with a few small white inclusions. Interior and exterior burnished gray (Gley $14 / \mathrm{N})$.

Probably Late Bronze Age.

37 Jar/table amphora rim

Fig. 13

Sector vw3.263:8. Est. Diam. 0.20 m. A sixteenth of the rim preserved. Slightly flaring rim. Fabric gray/brown (10R 5/1) with white inclusions. Interior and exterior burnished gray (Gley $14 / \mathrm{N})$.

Late Bronze Age or Early Archaic.

38 Table amphora rim

Fig. 13

Sector vw3.273:19. Est. Diam. 0.16 m. A quarter of the rim preserved. Flaring rim. Fabric brown (7.5YR 5/2) with gray edges, white inclusions. Exterior burnished gray (Gley $14 / \mathrm{N})$.

Late Bronze Age or Early Archaic.

39 Jar rim

Fig. 13

Sector vw3.322:8. Est. Diam. $0.28 \mathrm{~m}$. An eighth of the rim preserved. Rounded, flaring rim. Fabric gray/brown (10R 5/1), fairly fine. Interior and exterior burnished dark gray (Gley 1 3/N).

Late Bronze Age or Early Archaic.

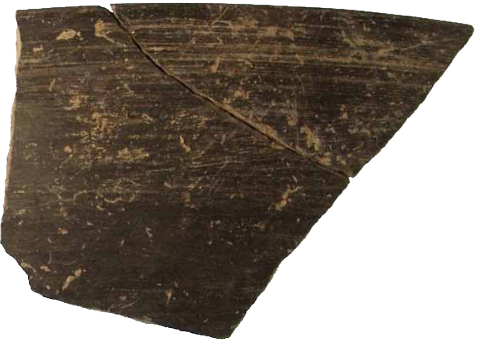

33

Figure 12. Gray ware bowls 32, 33.

Scale 1:2. Photos G. Bieg; drawings

M. Möck-Aksoy 


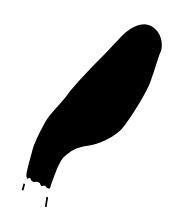

34

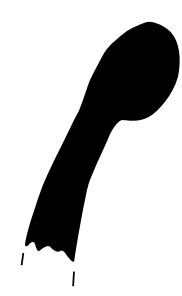

35

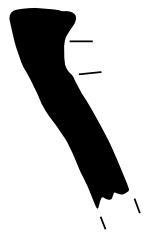

36

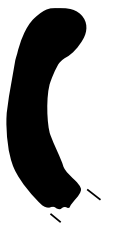

39

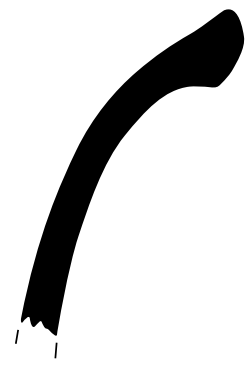

40

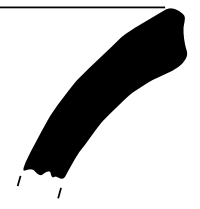

37

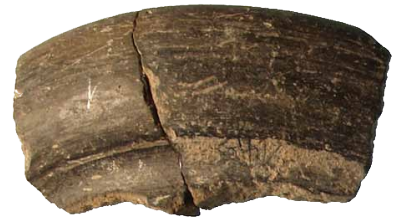

34

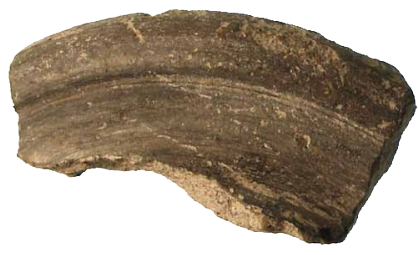

38

Figure 13. Gray ware table amphoras and jars 34-40. Scale 1:2. Photos G. Bieg; drawings M. Möck-Aksoy

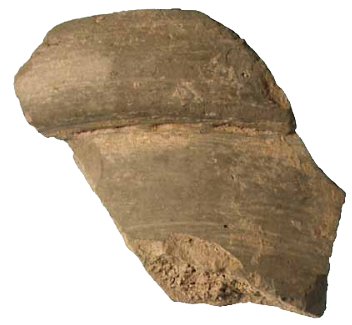

35

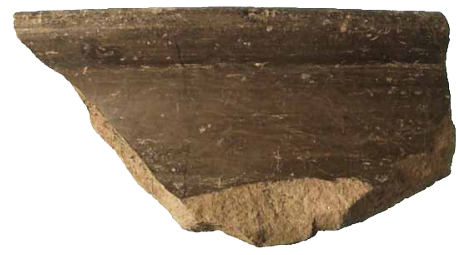

39

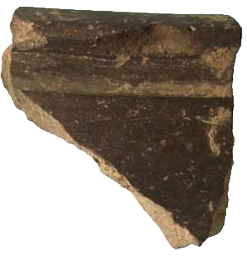

36

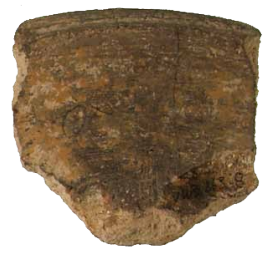

37
40 Table amphora rim

Fig. 13

Sector vw3.347:2. Est. Diam. 0.18 m. An eighth of the rim preserved. Flaring rim with thickened, rounded profile. Fabric gray/brown (2.5 YR 5/1) with white and gray inclusions, silver mica. Burnished gray/brown (2.5YR 5/1).

Late Bronze Age or Early Archaic. 


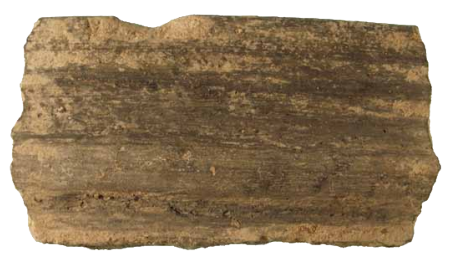

41

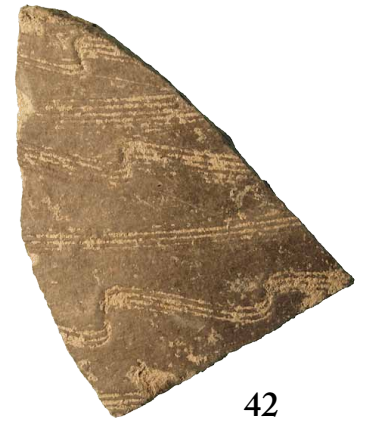

Fig. 14

41 Krater base

Fig. 14

42 Krater body fragment

Sector vw3.289:1. Max. p. dim. 0.085 m. Fabric gray (Gley $16 / \mathrm{N}$ ) with a few
11 white inclusions, mica. Decorated with bands of incised wavy and horizontal small white inclusions, mica. Decorated with bands of incised wavy and horizontal lines. Exterior burnished gray (Gley $14 / \mathrm{N})$.

Late Bronze Age or Early Archaic.

43 Krater body fragment

Fig. 14

Sector vw3.269:1. Max. p. dim. 0.058 m. Fabric gray at core (Gley 1 $4 / \mathrm{N}$ ) with lighter edges, a few small white inclusions. Exterior has a small knob, incised wavy and horizontal lines. Interior and exterior burnished gray (Gley 1 $5 / \mathrm{N})$.

Late Bronze Age or Early Archaic.

44 Krater/jar rim

Fig. 15

Sector vw3.286:9. Est. Diam. $0.215 \mathrm{~m}$. An eighth of the rim preserved. Shoulders slope away from the rim. Fabric dark gray (5YR 4/1) with a few white inclusions. Incised wavy line along the narrow ledge rim. Two very faint incised lines on the exterior. Interior and exterior burnished tan/gray (5YR 6/2).

Probably Early Archaic.

45 Krater rim

Fig. 15

Sector vw3.286:18. Est. Diam. $0.30 \mathrm{~m}$. An eighth of the rim preserved. Wide ledge rim. Fabric gray (Gley $16 / \mathrm{N}$ ) with darker edges, fairly fine, some mica visible. Exterior and interior burnished gray (Gley $15 / \mathrm{N}$ ).

Probably Early Archaic.

46 Large jar/dinos rim

Fig. 15

Sector vw3.286:12. Est. Diam. 0.25 m. An eighth of the rim preserved. Upper part of vessel slopes inward. Fabric gray/brown (10R 5/1), not very fine, with white and brown inclusions. Incised lines on exterior. Exterior lightly burnished gray $($ Gley $15 / \mathrm{N})$; interior unburnished.

Late Bronze Age or Early Archaic.

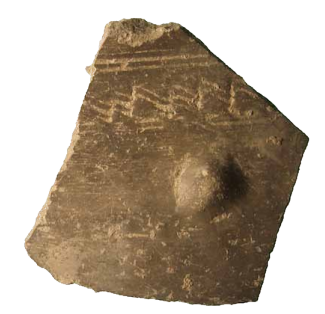

43

Figure 14. Gray ware kraters 41-43. Scale 1:2. Photos G. Bieg 


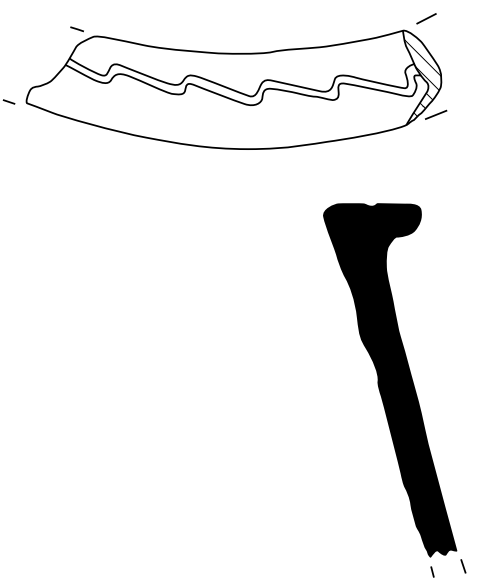

44

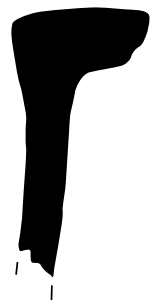

45

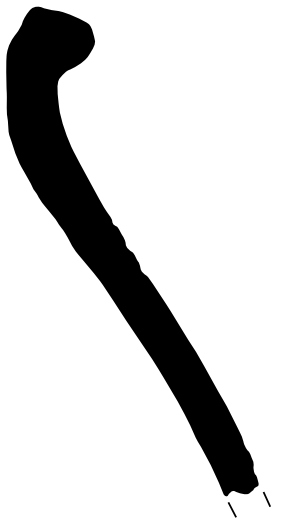

46

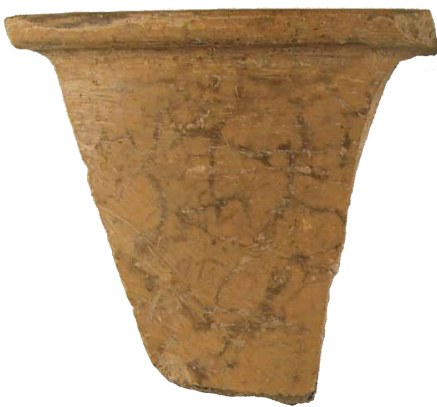

44

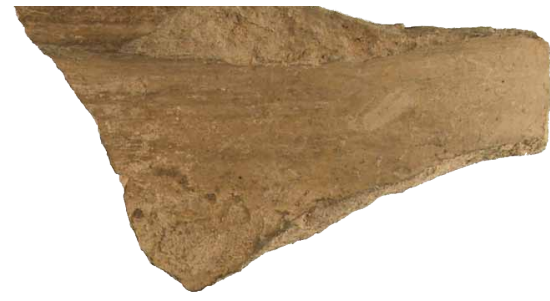

45

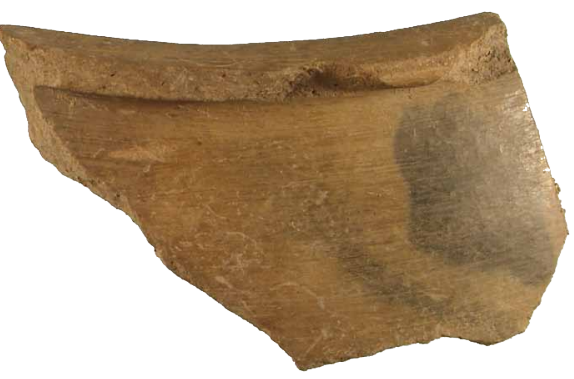

47

Figure 15. Gray ware kraters, dinoi, or large jars 44-47. Scale 1:2. Photos G. Bieg; drawings M. Möck-Aksoy

47 Dinos rim

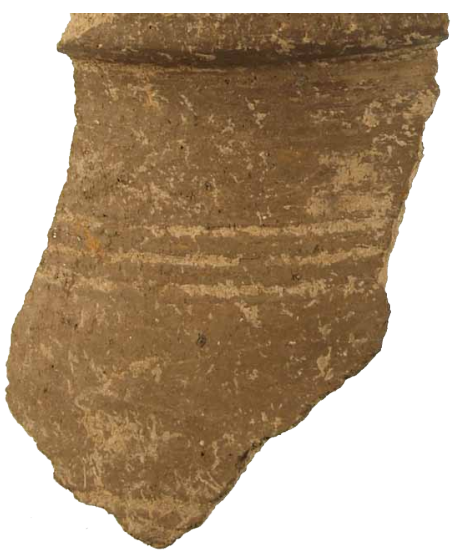

46

Sector vw3.273:26. Est. Diam. 0.23 m. An eighth of the rim preserved. Ledge rim. Fabric gray at core fading into areas of dark brown to light brown, with white sand inclusions, faint traces of mica. Interior and exterior burnished brown with uneven gray spotted areas.

Probably Early Archaic. 


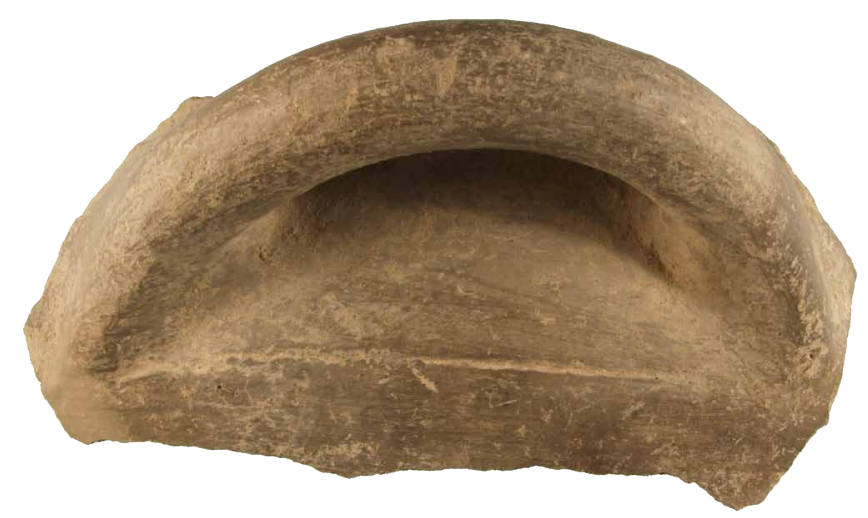

48 Large jar handle and body fragment

Fig. 16

Sector vw3.273:13. Max. p. dim. 0.197 m. Round horizontal handle. Fabric gray/brown (2.5 YR 5/1) with many white sand inclusions, silver mica. Incised line on the body under the handle. Exterior burnished gray (Gley $16 / \mathrm{N})$; interior unburnished. Blegen shape $\mathrm{C} 68$ or $\mathrm{C} 70$.

Late Bronze Age

\section{Grittit Ware}

49 Large jar rim

Fig. 17

Sector vw3.273:22. Est. Diam. 0.30 m. Less than a sixteenth of the rim preserved. Part of a handle scar on the rim. Fabric gray (Gley $15 / \mathrm{N})$ with many white sand inclusions, traces of mica. Interior and exterior burnished gray (Gley $15 / \mathrm{N})$. Blegen shape $\mathrm{C} 76$ or $\mathrm{C} 60$.

Late Bronze Age.

50 Large jar rim

Fig. 17

Sector vw3.269:2. Est. Diam. 0.28 m. An eighth of the rim preserved. Rounded rim. Fabric red/brown (2.5YR 5/6), gritty with white sand inclusions. Interior and exterior are an uneven brown/gray, smoothed but unburnished. Somewhat similar to Blegen shape C60.

Probably Late Bronze Age.

51 Large jar rim

Fig. 17

Sector vw3.353:4. Est. Diam. $0.30 \mathrm{~m}$. Less than a sixteenth of the rim preserved. Fabric brown at core (5YR 5/4) with gray edges (Gley $14 / \mathrm{N}$ ), many sand inclusions. Exterior and interior are mottled gray/brown. Blegen shape $\mathrm{C} 60$.

Late Bronze Age.

52 Large jar or cooking vessel rim

Fig. 17

Sector vw3.353:2. Est. Diam. 0.34 m. A sixteenth of the rim preserved. Fabric dark brown and gray mottled with many small sand inclusions, mica. Interior and exterior are mottled gray/brown. Wheel ridges visible. Similar to Blegen shape C65. Late Bronze Age.

53 Large jar rim

Fig. 17

Sector vw3.344:3. Est. Diam. 0.25 m. An eighth of the rim preserved. Outcurving rim. Fabric brown (2.5YR 5/4) with white and brown rocky inclusions. Exterior is unburnished. Interior has a little burnishing. Brown surface (2.5YR 5/4). Blegen shape C60 or C69.

Late Bronze Age.
Figure 16. Gray ware large jar 48. Scale 1:2. Photo G. Bieg 


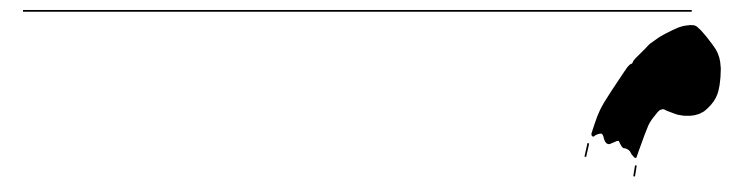

50

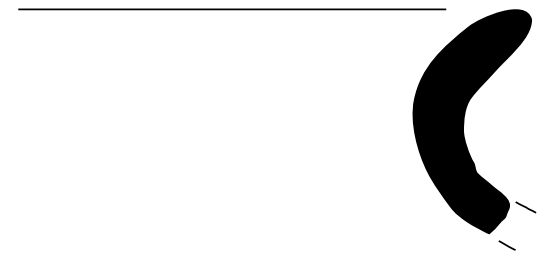

55
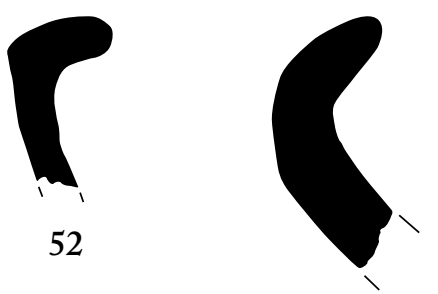

53

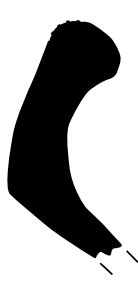

54

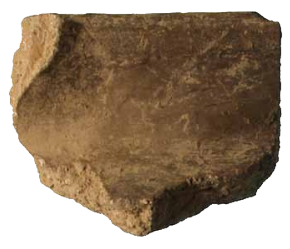

49

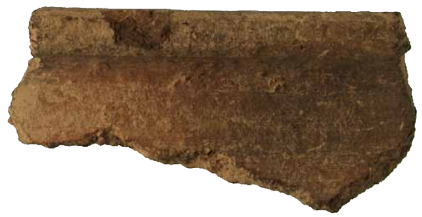

52

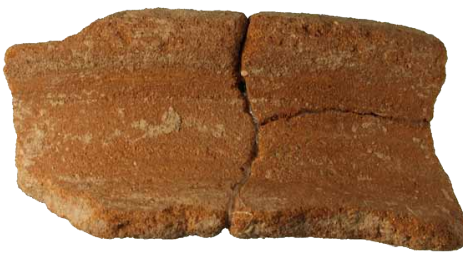

54

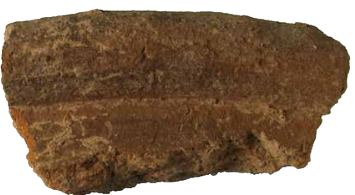

50

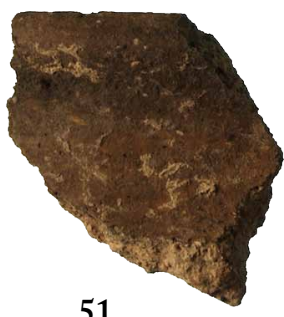

51

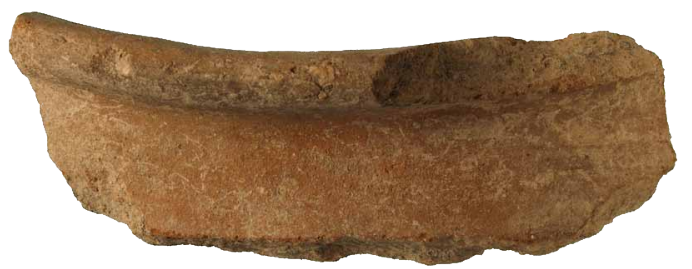

53

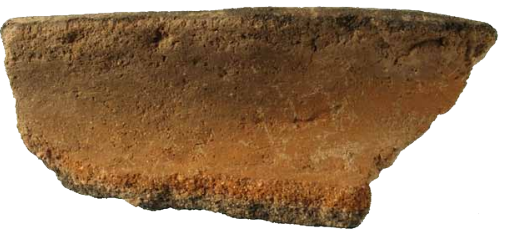

55

Figure 17. Gritty ware jars 49-55.

Scale 1:2. Photos G. Bieg; drawings

M. Möck-Aksoy 
Sector vw3.286:8. Est. Diam. 0.30 m. Less than a sixteenth of the rim preserved. Short neck. Unusual fabric: brown (5YR 5/4), very gritty, with many small sand inclusions. Unburnished, sandy, rough brown surface (5YR 5/4). Similar to Blegen shape C68.

Probably Late Bronze Age.

55 Large jar rim

Fig. 17

Sector vw3.28:29. Est. Diam. 0.38 m. Less than a sixteenth of the rim preserved. Flaring rim. Fabric gray (Gley $14 / \mathrm{N}$ ) with brown edge on exterior, very gritty, with sand inclusions. Slightly smoothed, no burnishing. Exterior is uneven brown/gray, interior is dark gray. Blegen shape $\mathrm{C} 60$ or $\mathrm{C} 69$.

Late Bronze Age.

\section{Large Jars in Other Coarse Fabrics}

56 Large jar rim

Fig. 18

Sector vw3.273:32. Est. Diam. 0.36 m. Less than a sixteenth of the rim preserved. Fairly deep cuts along the rim, probably made with a knife or tool. Handmade. Fabric red/brown (2.5YR 4/3) with many sand inclusions, a little silver mica. Exterior and interior lightly burnished. Red/brown surface (2.5YR 4/3).

At Troy these handmade coarse-ware vessels usually occur in the VIIb period, but there is one from the Troy VI cemetery excavated by Blegen (Troy III, p. 373, no. 34.313 , fig. 305 ).

57 Large jar handle and body fragment

Fig. 19

Sector vw3.286:19. Max. p. dim. 0.17 m. Two joining fragments preserving handle and part of body. Large round handle. Fabric gray at core (Gley $14 / \mathrm{N}$ ) with brown edges, white and gray inclusions. Unburnished. Surface is pink (10R 6/6). Blegen shape C68, C69, or C70.

Late Bronze Age.

\section{CoOKIng Ware}

58 Cooking pot or storage vessel rim

Fig. 20

Sector vw3.273:45. Est. Diam. 0.17 m. A sixteenth of the rim preserved. Fabric on inner half light gray (Gley $16 / \mathrm{N})$, on outer half gray (Gley $14 / \mathrm{N})$, with some sand inclusions. Wheelmade, slightly smoothed, with self-slip.

Atypical for both Late Bronze Age and Early Archaic period.

59 Cooking pot rim

Fig. 20

Sector vw3.305:2. Est. Diam. 0.10 m. A sixteenth of the rim preserved. Slightly flaring rim. Fabric dark gray (Gley $13 / \mathrm{N})$ with many small sand inclusions. Mottled brown/gray.

Probably Early Archaic.

60 Cooking pot rim

Fig. 20

Sector vw3.273:33. Est. Diam. $0.12 \mathrm{~m}$. An eighth of the rim preserved. Fabric dark gray (5YR 3/1) with white sand inclusions, faint traces of silver mica. Dark gray surface, encrusted with salt on exterior and interior. Wheelmade.

Early Archaic.

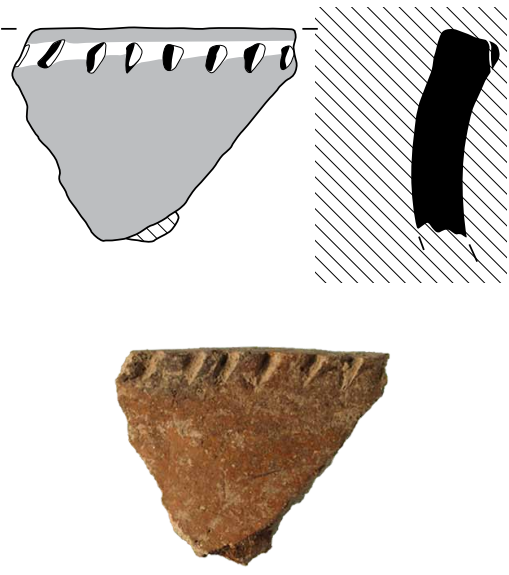

Figure 18. Handmade coarse-ware jar 56. Scale 1:2. Drawing M. Möck-Aksoy; photo G. Bieg

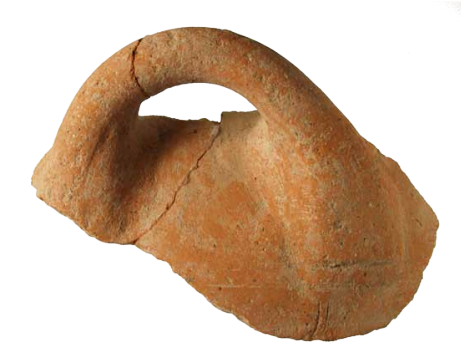

Figure 19. Coarse-ware large jar 57. Scale 1:4. Photo G. Bieg 


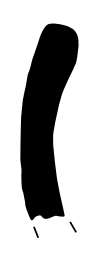

58

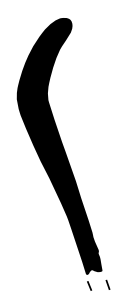

60

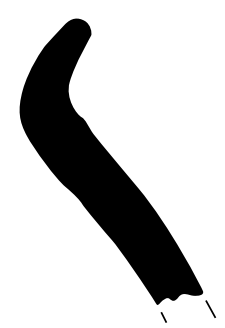

61

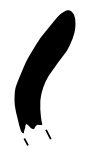

62

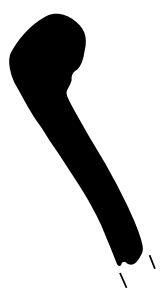

63

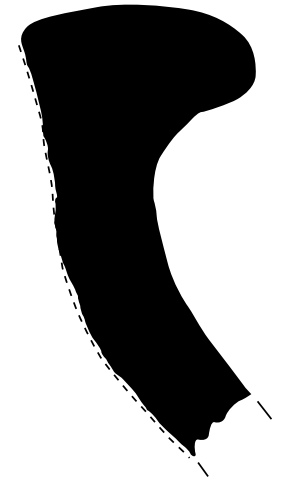

64

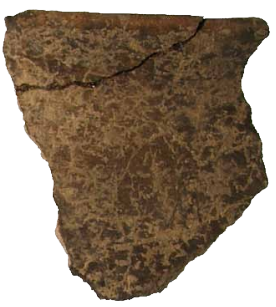

60

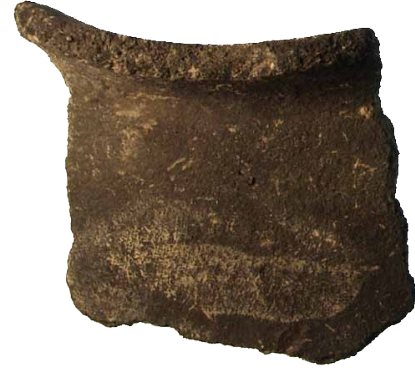

61
59

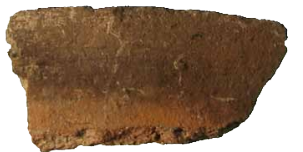

62

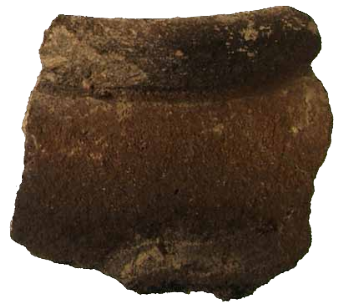

63

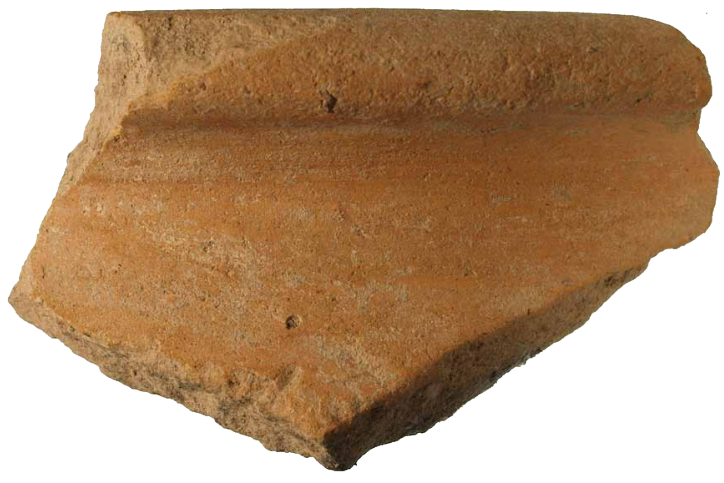

64
Figure 20. Cooking pots or storage

jars 58-63 and pithos 64. Scale 1:2.

Photos G. Bieg; drawings M. Möck-Aksoy
Fig. 20

61 Cooking pot or storage vessel rim

Sector vw3.353:1. Est. Diam. 0.14 m. An eighth of the rim preserved. Fabric dark gray (Gley $13 / \mathrm{N}$ ) with many small sand inclusions. Interior and exterior are dark gray (Gley $13 / \mathrm{N})$. Thick walls with wheel ridges visible on interior. Blegen shape C68.

Late Bronze Age. 
62 Cooking pot rim

Fig. 20

Sector vw3.273:44. Est. Diam. 0.15 m. An eighth of the rim preserved. Fabric brown (5YR 5/3) with sand inclusions and a few larger pebbles, silver mica, and a small amount of gold mica. Upper part of rim is blackened on exterior and interior; remainder is brown (5YR 5/4). Surface smoothed, with self-slip. Wheelmade.

Probably Early Archaic.

63 Cooking pot or storage jar rim

Fig. 20

Sector vw3.353:3. Est. Diam. $0.16 \mathrm{~m}$. An eighth of the rim preserved. Fabric gray (Gley $14 / \mathrm{N})$ with many small sand inclusions. Interior and exterior are mottled black/brown. Wheelmade, with thick, heavy walls. Blegen shape C77.

Late Bronze Age.

Pithos

64 Pithos rim

Fig. 20

Sector vw3.273:50. Est. Diam. 0.40 m. Triangular ledge rim. Fabric dark gray (5YR 4/1) with some rocky gray inclusions. No decoration. Fairly smooth tan/ pink surface (5YR 7/4).

Probably Late Bronze Age.

\section{SMALL FINDS}

65 Wedge-shaped clay object (scraper?)

Fig. 21

Sector vw3.314:2. L. 0.033 m. One side is sharpened like a wedge. Fabric pink/orange (2.5YR 6/6), fine. No decoration. Light brown ground (2.5YR 6/4). Probably Early Archaic.

66 Ceramic object (handle attachment?)

Fig. 21

Sector vw3.311:1. L. 0.034 m. Two edges preserved. Fabric tan/orange (2.5YR 6/8), fine. Glossy red paint on all sides (10R 4/8).

Late Bronze Age or Early Archaic.

67 Clay vessel attachment

Fig. 21

Sector vw3.356:4. Max. p. dim. $0.061 \mathrm{~m}$. Vessel or handle attachment in the shape of an animal head. One ear and part of the nose are broken. Fabric gray (Gley $14 / \mathrm{N}$ ) with white inclusions, mica. Burnished dark gray (Gley $13 / \mathrm{N}$ ).

Probably Late Bronze Age.

68 Clay knob

Fig. 21

Sector vw3.311:4. H. 0.022 m. Fabric gray/brown (10R 5/1) with white inclusions. Burnished gray (Gley 1 4/N).

Late Bronze Age or Early Archaic.

69 Bronze fibula

Fig. 21

Sector vw3.276. L. $0.071 \mathrm{~m}$; weight $4.3 \mathrm{~g}$. Only the pin is preserved.

Late Bronze Age or Early Archaic.

70 Bronze pin or fibula

Fig. 21

Sector vw3.359. L. 0.027 m; weight 0.6 g. Fragment of a pin or fibula.

Late Bronze Age or Early Archaic. 


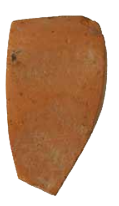

65
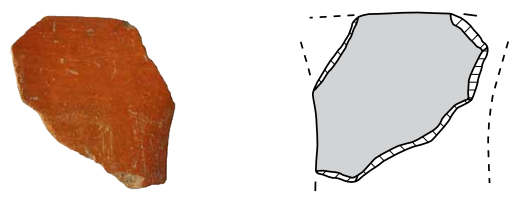

66

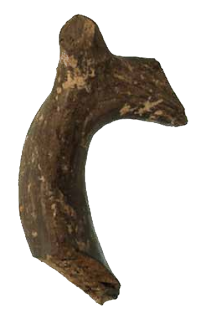

67

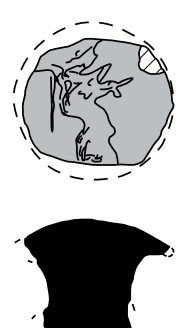

68

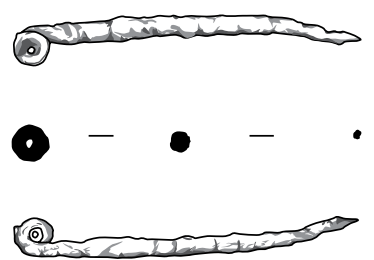

69

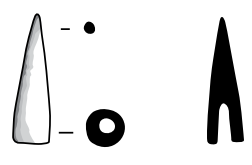

71

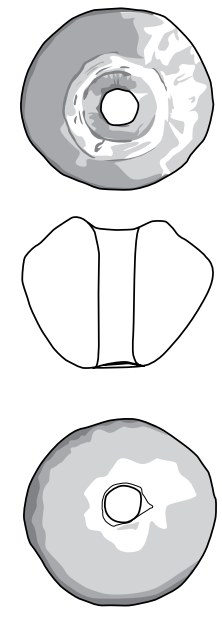

72

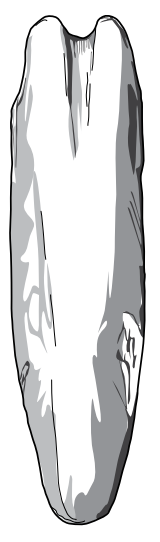

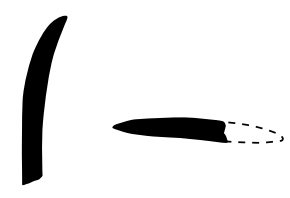

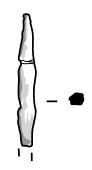

70

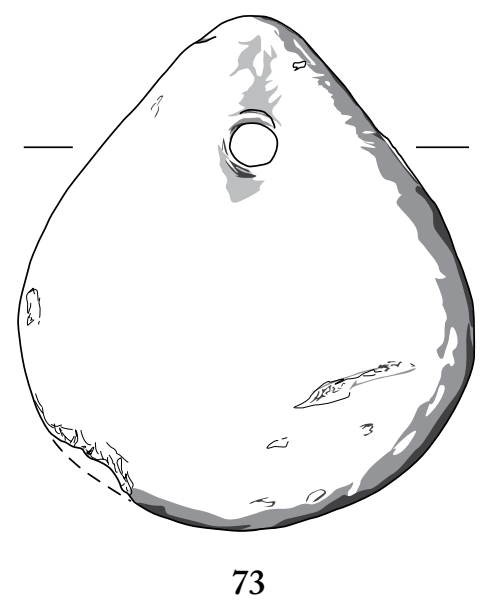

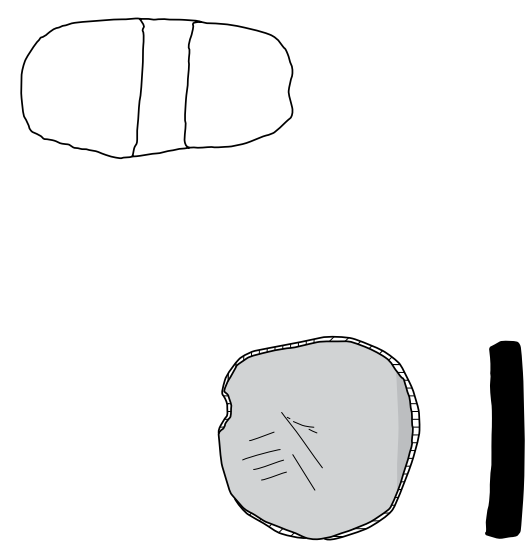

74
Figure 21. Small finds 65-74. Scale 1:2. Drawings M. Möck-Aksoy
71 Bone point

Fig. 21

Sector vw3.266. L. $0.026 \mathrm{~m}$; weight $1.2 \mathrm{~g}$. A hole in the base extends halfway up the length.

Late Bronze Age or Early Archaic. 
72 Clay spindle whorl

Fig. 21

Sector vw3.272. W. 0.031 m; weight 37 g. Conical. Brown/gray fabric.

Probably Late Bronze Age, Blegen form 22 or 23.

73 Clay loom weight

Fig. 21

Sector vw3.304. L. 0.102 m; weight 232 g. Pear shaped. Gray fabric.

Similar to Troy III, p. 232, no. 34.177, fig. 305. Probably Late Bronze Age.

74 Worked sherd

Fig. 21

Sector vw3.340. Max p. dim. 0.041 m; weight 13.2 g. Round.

Late Bronze Age or Early Archaic.

\section{Discussion}

The Late Bronze Age material dates to the late Troy VI period. Painted Mycenaean pottery (LH IIIA1-IIIA2) is present in small amounts (8-12 possible fragments). ${ }^{24}$

The date of the Early Archaic material depends on the chronology of $\mathrm{G} 2 / 3$ ware (1-14). G2/3 ware is a regional fine ware with small geometric motifs found at Troy and other sites in the northeastern Aegean, such as Samothrace, Lemnos, Lesbos, Tenedos, and Thasos. ${ }^{25}$ Earlier and later forms of the ware can be distinguished at Troy; that found at the Place of Burning is of the later type. ${ }^{26}$ This type has been dated from the late 8 th to the first half of the 7 th century on the basis of stratified contexts at Troy, where G2/3 ware has been found under levels containing late-7th-century ceramics such as Wild Goat style. ${ }^{27}$ Some early-7th-century imports from Chios were found with $\mathrm{G} 2 / 3$ ware in sector $\mathrm{K} 4 / 5,{ }^{28}$ and one cup rim from the Place of Burning (16) has a parallel at Samos dated before 660. These support a date of ca. 725/700-650 for the later type of G2/3 ware.

The pottery assemblage is unusual in several ways, first and foremost for the amount of Late Bronze Age material found together with that of the Early Archaic period. Almost everywhere at Troy, small numbers of Bronze Age sherds, usually fragmentary and worn, appear as residual pieces in later

24. Penelope Mountjoy, who will publish the Mycenaean material from this area in her final report on the Mycenaean pottery at Troy, kindly provided the dates.

25. Samothrace: Moore 1982, pp. 318-370. Lemnos: Messineo 2001, pp. 123-144; Beschi 2003a, pp. 329-

341; 2003b, pp. 1007-1014, pls. 8-20; Danile 2008, pp. 41-43, no. 7, pl. 5; 2011, pp. 93-99, fig. 74. Lesbos: Lamb 1931-1932, p. 56, nos. 6-13, pl. 23. Tenedos: Arslan and Sevinç 2003, p. 229 , nos. 1.4 , 1.5, fig. 6 . Thasos: Bernard 1964, pp. 88-109; Graham 1978, pp. 67-70. According to a neutron activation analysis of samples from Troy (Mommsen, Hertel, and Mount- joy 2001), G2/3 ware was locally or regionally produced. For general discussion, see Ilieva 2009, pp. 98-109; Fisher 1996.

26. For the distinction between the two types, based on evidence from excavations in sector D9, see Aslan 2002, pp. 92-93. Hertel (2008b, pp. 113-124) has suggested that activity at the Place of Burning began in the 9th century, on the basis of Blegen's comment (Troy IV, p. 299) that certain types of gray ware cups and kraters found there were similar to the Protogeometric (PG) shapes illustrated in Troy IV, fig. 317:2, 3, 31. Blegen did not illustrate any examples from the Place of Burning, and I have not observed any of these types in the newly excavated material. Two PGstyle amphoras $(20,21)$ are probably later types, for PG amphoras continue to be found at Troy until the Late Geometric-Early Archaic period.

27. Aslan 2002, pp. 92-93; see also Fisher 1996; 2000, pp. 78-86. For further discussion of the dating of G2/3 ware, see Graham 1978, pp. 67-70; Ilieva 2009, pp. 109-111. The earlier form of $\mathrm{G} 2 / 3$ ware may begin as early as the 9th century, as Hertel has proposed (2007, p. 106). This form, however, does not occur at the Place of Burning.

28. Aslan 2009b, pp. 37, 42-43, nos. 28-32. 
contexts. Here, however, the quantity and large size of the LBA fragments indicate that some uncommon activity caused the mixing of earlier and later ceramics. It is difficult to calculate the precise percentages of wares from the two periods because of the uncertainty in distinguishing between Troy VI gray ware and that of the Archaic period (22-48). Gray ware at Troy has a long tradition, and a large portion of the profile is usually required to determine whether a vessel has a LBA or Archaic shape. ${ }^{29} \mathrm{I}$ estimate that at least $50 \%-60 \%$ of the pottery from the mixed contexts dates to the Early Archaic period, and the rest is mostly Late Bronze Age, although there is some residual material from the Early and Middle Bronze Age (Table 1).

A second notable aspect of the pottery from the Place of Burning is its quantity, when compared with deposits of a similar date from excavated areas of comparable size elsewhere at Troy (sectors D9, K4/5, and the West Sanctuary). Excavations at the Place of Burning produced ca. 3,500 sherds, with 367 rim sherds. By comparison, excavators recovered only 46 rim sherds from the Early Archaic levels in sector D9, and only 81 rim sherds from sector $\mathrm{K} 4 / 5 .{ }^{30}$ Blegen also appears to have been impressed by the "great quantity" of ceramics from the Place of Burning. ${ }^{31}$ Although many of the fragments are fairly large and not very worn, few joining sherds were found. This may indicate that the excavated material forms part of a much larger deposit dispersed over a broader area, and that the two large pits did not receive whole vessels.

Finally, the quantities of certain types of vessels are also remarkable. The number of cups stands out as unusually high, with a total of 80 cup rims from the mixed contexts. In spite of the difficulty of distinguishing Archaic and LBA gray ware, some of the cup shapes are chronologically distinctive. Thirteen gray ware and tan ware cups can certainly be attributed to the Troy VI period (22-25). Thirty-three of the gray ware cups can reasonably be assigned a date in the Early Archaic period (28-31), together with the 13 painted cup rims $(1-5,15-17)$. Although some cups $(26,27)$ cannot be definitively dated, at least half, and probably more, are from the Early Archaic period.

Large jars dominate the assemblage even more than cups. Forty-eight large gritty ware jar rims (49-55) almost certainly date to the Late Bronze Age, and many gray ware jars, kraters, and dinoi (41-48) probably belong to the same period, although it is difficult to be certain without complete profiles.

Blegen's conclusion that the area was used for cremations was based partly on the presence of LBA vessels similar to the cinerary urns found in the Troy VI cemetery south of the citadel. There Blegen found 19 burials in cremation jars and a large area with broken fragments of other jars, as well as parts of four pithoi. The burials were fairly close to the modern surface, making them vulnerable to later discovery and breakage. Most

29. Hertel (2007) argues for significant differences between so-called Aiolian gray ware and Late Bronze Age gray ware. Although some changes in shape certainly occur (see Bayne 2000), when working with the highly frag- mented material from Troy it is very difficult and often impossible to differentiate between Bronze Age and Early Archaic forms.

30. The contrast is all the more striking in that the contexts in sectors D9 (phase 4, Beh. 2925, 2927, 2929, 2930, 2932; Aslan 2002) and K4/5 (Beh. 62, 73; Aslan 2009b) both appear to be refuse deposits, which one would expect to contain large quantities of ceramics.

31. Troy IV, p. 299. 
of the cinerary urns were of Blegen shapes C68, C70, and C76, in either gray or gritty ware. These are also common shapes at the Place of Burning. Bronze Age cooking pots, jars, and a pithos found at the Place of Burning $(56-58,61,63,64)$ may also have been used as burial containers.

Some of the graves in the south cemetery contained small bowls or cups in gray ware, and a few had small Mycenaean vessels. A limited number of other objects were discovered in the graves as well, including beads, spindle whorls, pins, rings, and ivory. ${ }^{32}$ Similar burial customs are evident in the Late Bronze Age cemetery at nearby Beşiktepe, where most of the graves are cremation burials in jars, or occasionally in pithoi, containing small ceramic vessels and other objects like those found at Troy. ${ }^{33}$ The range of ceramics found in these burials corresponds well with the LBA material found at the Place of Burning, including large vessels in gritty and gray wares that could have been cremation urns, as well as smaller cups and bowls in gray and tan wares and a small amount of Mycenaean pottery. The small finds from the Place of Burning are not numerous, but include a spindle whorl (72), a loom weight (73), a pin (70), and a bone point (71), all of which are possible grave goods. ${ }^{34}$ One fibula fragment (69) is probably Early Archaic.

On the basis of the types of pottery as well as the human bone fragments found there, Blegen's conclusion that the Place of Burning was either a cremation site or a Late Bronze Age cemetery is reasonable. Although it may be odd to argue for a cemetery where no intact burials remain, the ceramic assemblage is significantly unusual, and it is difficult to find another explanation for the discovery of ca. 50 possible cinerary urns in this area during the 2003-2005 excavations, apart from those that Rawson must have found in 1932. For some reason, none of the burials appears to have remained intact, and the broken urns and their contents have become extensively mixed with Early Archaic material.

Two questions remain: what was the function of the Early Archaic pottery, and why is it mixed with material from the Late Bronze Age burials? The ceramics that can be identified as certainly or probably Early Archaic include an unusually high number of fine-ware cups in gray and painted wares $(1-10,15-17,28-31), 16$ cooking pots $(59,60$, 62), and some jugs, jars, and amphoras in plain or painted wares (11-13, 18-21, 34, 35). Many of the gray ware table amphoras, bowls, and jars $(32,33,38-40)$ are probably Early Archaic as well. One possibility is that this material represents domestic debris left by inhabitants living in the oval structure at the edge of the settlement. The quantity of the pottery, however, and especially the large number of cups, is not typical of a standard domestic trash assemblage when compared with rubbish deposits of the same period found closer to the mound in sectors K4/5 and D9. ${ }^{35}$ The long, narrow trenches dug by Blegen's team produced no evidence of other habitation in this area, and it is unlikely that such a

32. Troy III, pp. 370-391.

33. Basedow 2000, esp. pp. 115-120, pls. 48-51; see also pp. 121-144 for the small finds.

34. Some of these objects may date to the Early Archaic period. It should be noted, however, that Early Archaic contexts at Troy rarely contain small finds.

35. See n. 30, above. 
large quantity of pottery could have been used by the inhabitants of this one building.

Blegen suggested a second possibility: that cremations were conducted at the Place of Burning in the Archaic period as well. ${ }^{36}$ We know very little about burial practices in the Troad during the Early Archaic period. At Troy there is one Late Geometric inhumation burial in sector D9; the body was partly covered with pithos sherds. ${ }^{37}$ In the Early Archaic period both cremation and inhumation burials were placed into cist graves on the nearby island of Tenedos. ${ }^{38}$ Only five graves have been found there, so the sample is small. They tend to contain a few small ceramic vessels and some small metal items such as fibulae. Early Archaic burial customs on Lesbos are not well known, but also seem to have consisted of a mix of cremation and inhumation. ${ }^{39}$ It is possible that an area near the Place of Burning was used for burials in the Archaic period and that the activity at the oval structure was connected with these burials, but no clear evidence supports this interpretation.

Since none of these suggestions fits the evidence well, I offer a new interpretation: that the oval structure was a place for rituals, specifically ritual feasting, and that it was deliberately built above a Late Bronze Age cemetery. The Early Archaic ceramics, and in particular the many cups, could have been used for communal feasting. This explanation would account for the quantity of the pottery, which is too much for a single household. The fact that the oval structure was built in an uninhabited area, away from the settlement, may indicate that it was intentionally, not accidentally, placed at the location of the Late Bronze Age cemetery. I suggest that in the early 7th century the inhabitants of Troy rediscovered the Bronze Age cremation urns (or perhaps the cemetery had never been forgotten) and began ritual activity at the site of the old burial ground. ${ }^{40}$

A final important point should be noted about the ceramics from the Place of Burning: no material from the second half of the 7 th or from the 6 th -5 th centuries has been found there. Activity must have ceased sometime around the mid-7th century, and no one appears to have used the area again until burials resumed in the Hellenistic period. Evidence from other parts of Troy indicates a destruction at the site in the mid-7th century, either from an earthquake or from hostile action. ${ }^{41}$ The burned material and fallen stones found by Rawson within the building at the Place of Burning could have been a product of the same destruction event. Actions such as looting during or after the period of destruction would have mixed the Archaic and Bronze Age ceramics together in broken, scattered fragments. The entire site of Troy may have been abandoned for a time, or reduced to a very low population. Eventually, in the late 7th-early 6th century, the inhabitants rebuilt the West Sanctuary, but they did not rebuild at the Place of Burning.

36. Troy IV, p. 299. 2002.

37. Rose 1999, pp. 37-38; Aslan

38. Arslan and Sevinç 2003.

39. Spencer 1995, pp. 294-295.
40. A possible objection to this interpretation is that no Early Archaic figurines or other objects that can be considered votive were found at the Place of Burning. The entire site of
Troy, however, has so far produced no figurines dating to this period, and few other small finds.

41. Aslan 2009b. 


\section{CULT BUILDINGS AND CEMETERIES}

The shape of the building at the Place of Burning is unusual at Troy. No other oval structure has been found at the site, although not many buildings from the Early Archaic period survive at all, and the builders of the Hellenistic temple and temenos of Athena may have removed or covered over much of the Archaic architecture that once existed within the citadel walls. ${ }^{42}$

In the wider region, however, buildings of similar shape appear at a number of sites in the Late Geometric and Early Archaic periods. ${ }^{43}$ At several sites on Lesbos, oval structures dating to the late 8th-7th century have been interpreted as possible cult buildings. ${ }^{44}$ An oval or apsidal building at Antissa probably dates to the same period as that at the Place of Burning, to judge from the G2/3 ware found there..$^{45}$ The building is somewhat larger than the one at Troy $(14 \times 6.1 \mathrm{~m})$, and it is uncertain whether it functioned as a temple or as a house. ${ }^{46}$ An oval structure at Mytilene is also thought to have been a temple, possibly for Cybele or Apollo, although the identification is open to doubt, and the dimensions are uncertain. ${ }^{47} \mathrm{It}$ was built ca. 700 and continued in use through the 6th century. At Pyrrha an oval or perhaps apsidal building has been interpreted as a sanctuary of Apollo and/or Artemis. ${ }^{48}$ It appears to have been constructed in the 8th century and later remodeled.

Excavations have also revealed similar buildings elsewhere in western Anatolia. Among a group of Late Geometric oval buildings at Miletos is one slightly larger than the one at Troy $(11.50 \times 6 \mathrm{~m}) .{ }^{49}$ The structures at Miletos are quite fragmentary, with thin walls, and again it is not clear whether they were sacred or secular in function. At Ephesos an oval or apsidal structure, possibly an early cult building, was discovered under the temple of Artemis. ${ }^{50}$ Some curving walls at Smyrna probably belong to oval houses from the late 8th-early 7 th century. ${ }^{51}$

Although several of these oval structures have been interpreted as cult buildings, the shape alone is not enough to indicate such a function at the Place of Burning. It may be more informative to consider other structures of the 8th and 7 th centuries that were built near graves and appear to have been the settings for rituals in honor either of the recently deceased or of more distant heroes or ancestors.

A possible example of such a cult building placed within an earlier cemetery exists at Athens, where the fragmentary walls of an oval building

42. Archaic architectural remains include wall fragments in sectors $\mathrm{J} 5$ and K7 (Troy IV, pp. 283, 285-286) and House 814 in sectors E/F 8-9 (Troy IV, pp. 287-288, fig. 336; Basedow 2009, pp. 132-142). The architecture in the West Sanctuary is discussed below. 43. Mazarakis Ainian 1997, p. 84. For Iron Age and Early Archaic architecture, see also Fagerström 1988; Lang 1996.

44. Lamb 1931-1932, pp. 44-48;
Fagerström 1988, p. 89; Spencer 1995, pp. 285-287, 296-299; Mazarakis Ainian 1997, pp. 89-93. 45. Spencer 1995 , p. 285; Mazarakis Ainian 1997, p. 91.

46. Mazarakis Ainian 1997, pp. 91-92.

47. Spencer 1995 , pp. 296-299; Mazarakis Ainian 1997, pp. 89-91. Spencer reconstructs the building as $5.5 \times 8.3 \mathrm{~m}$, Mazarakis Ainian as $5.5 \times 14 \mathrm{~m}$.
48. Schiering 1989, pp. 351-355; Spencer 1995, p. 283; Mazarakis Ainian 1997, pp. 92-93.

49. Kleine 1979 , pp. 115-119, figs. 3, 4; Mazarakis Ainian 1997, pp. 109-110.

50. Bammer 1982, p. 61; Fagerström 1988, p. 97; Mazarakis Ainian 1997, p. 109.

51. Akurgal 1983, pp. 28-34, figs. 8, 15; Fagerström 1988, p. 91; Mazarakis Ainian 1997, pp. 108-109. 
$(11 \times 5 \mathrm{~m})$ were discovered near the southwestern corner of the Agora, in an area occupied by Protogeometric and Geometric graves; a Geometric child burial was found beneath the floor. Inside the building, a deep fill contained Protoattic pottery and many terracottas, and the assemblage has been interpreted as votive in nature. ${ }^{52}$ No direct evidence proves that the structure itself or the votives were used in rituals associated with the earlier burials in the area, although in her publication of the material Dorothy Burr noted similarities between the votives and other deposits connected with chthonic deities or heroes. ${ }^{53}$

The interpretation of the relationship between the graves, the oval structure, and the votive fill has been a matter of some discussion. ${ }^{54}$ Burr, the excavator, interpreted the structure as a house, with a later filling of votive material from a nearby sanctuary. ${ }^{55}$ Homer Thompson subsequently reinterpreted it as an open temenos for a cult of the dead. ${ }^{56}$ Kare Fagerström has proposed that it was originally intended as a house, and only later reused for religious activity. ${ }^{57}$ James Whitley has suggested that it was a cult building for an anonymous hero, but he finds it odd that such a simple burial would have been chosen as the focus for a cult. ${ }^{58}$ The same question-why were simple urn burials chosen for reverence?-applies as well to the LBA graves at the Place of Burning.

At Eleusis, Late Bronze Age (LH IIIC) cist graves were enclosed by a wall in the 8th century and Late Geometric pottery was found in the area. These may be the graves of the Seven against Thebes mentioned by Pausanias (1.39.2), although Carla Antonaccio has cast doubt on this interpretation. ${ }^{59}$ There are also several examples of enclosure walls or structures in cemeteries that probably delineated space for rituals in honor of more recently deceased ancestors. At Eretria a triangular monument was built over graves of the late 8th-early 7th century, and there is evidence that votive activity and sacrifices took place there. ${ }^{60}$ How much time passed between the burials and the beginning of ritual is unknown, although Whitley considers this an example of hero cult or tomb cult for the recently deceased. ${ }^{61}$ Similar enclosures are known from Naxos in the Geometric period, where curving or rectilinear walls were built above Protogeometric graves and in proximity to the ruins of a fortification wall and houses of the Late Bronze Age. The Geometric inhabitants also constructed circular platforms and left fragments of drinking vessels around them, in a manner reminiscent of the stone circles found at Troy (see below). ${ }^{62}$ The enclosure walls, circles, and remains of pyres have been interpreted as evidence for ritual activities honoring the dead. ${ }^{63}$

52. Burr 1933; Thompson 1968, p. 60.

53. Burr 1933, pp. 637-639.

54. Thompson 1968, p. 60; Fagerström 1988, pp. 44-46; Whitley 1988, p. 176; 1994, p. 225; Antonaccio 1995, pp. $122-125$.

55. Burr 1933, pp. 636-640.

56. Thompson 1968, p. 60.

57. Fagerström 1988, pp. 44-46.
58. Whitley 1994, p. 225.

59. Mylonas 1961, pp. 62-63;

Snodgrass 1980, p. 39; Whitley 1988, p. 176; Antonaccio 1995, pp. 112-117.

The Bronze Age tombs show signs of either reuse or robbing, and some were disturbed by later graves. Antonaccio has suggested that the wall may have been put up to protect the tombs after they were looted, or that it was built to make amends for their desecration.

60. Eretria III; Antonaccio 1995, pp. 228-235; Mazarakis Ainian 1997, p. 61 .

61. Whitley 1994, p. 220.

62. Lambrinoudakis 1988, p. 238.

63. Lambrinoudakis 1988; Mazarakis Ainian 1997, pp. 188-193. 
At Kyme in Euboia, an oval building of the Geometric period built above Geometric graves has been identified as a heroon; it is part of an early sanctuary with a stone circle nearby. The pottery and bones found outside the structure are interpreted as evidence for banqueting or other rituals ${ }^{64}$ In the Argolid, Asine is another site with structures that may have been used for funerary rituals, although in this case too the rituals may have honored recently deceased family members. ${ }^{65}$

The buildings and other structures described above were used for rituals in honor of the dead, whether distant ancestors and heroes or the more recently deceased. I have concentrated on examples of structures built within cemeteries, and have not included the numerous instances of votives left at Mycenaean tombs, or hero shrines unconnected with actual burials. ${ }^{66}$ Hero or ancestor cult is often associated with the conspicuous and impressive chamber and tholos tombs of the Late Bronze Age, such as these in the Argolid. Yet there are also instances, as at Athens and Eleusis, in which more modest and simple graves from earlier periods attracted attention and worship in the 8 th and 7 th centuries ${ }^{67}$ This may also have been the case at the Place of Burning.

\section{THE WEST SANCTUARY AND THE STONE CIRCLES}

The West Sanctuary is located directly outside the Troy VI fortification wall on the western side of the citadel (Fig. 1). Here Blegen and his team uncovered a series of altars dating to the Archaic, Hellenistic, and Roman periods, ${ }^{68}$ and further excavations in the 1990s revealed temples and other cult structures. ${ }^{69}$

A cult building was constructed in the middle of the sanctuary some time in the 9th century. The building is rectangular $(7.7 \times 13.15 \mathrm{~m})$ with a possible corridor along one side. An apsidal structure filled with ash was found inside the building, along with a statue base and several fibulae. ${ }^{70}$ The temple was rebuilt and remodeled in the 8th-early 7th century (Fig. 22), and this second phase was most likely in use at the same time as the structure at the Place of Burning. In the northern part of the sanctuary were a series of hearths, surfaces, and postholes also dating to the 8th or first half of the 7th century, indicating that perhaps another structure or open-air use area was located there.

Behind the temple, on a terrace or platform, are 28 stone circles, originally excavated by Blegen and his team (Figs. 22-24). ${ }^{71}$ The circles range

64. Sapouna-Sakellaraki 1998, pp. 61-68.

65. Mazarakis Ainian 1997, pp. 69-72.

66. These are well documented in Antonaccio 1995.

67. See also Antonaccio 1995 , pp. 199-243, 250-251.

68. Troy IV, pp. 262-267. Blegen refers to the "Upper and Lower Sanctuaries," but in more recent scholarship the name "West Sanctuary" is preferred. 69. For preliminary reports, see Rose 1993, pp. 98-101; 1994, pp. 7680; 1995, pp. 82-97; 1997, pp. 74-92; 1998, pp. 73-92; 1999, pp. 49-52; 2000, pp. 54-58. A series of final reports is in preparation. See also Basedow 2006; 2009, pp. 131, 135, 139; Aslan 2009a, pp. 147, 149-150; 2009c; and the final excavation report on the Protogeometric, Geometric, and Ar- chaic remains from the West Sanctuary (forthcoming in Studia Troica). There was probably a hiatus in activity in the sanctuary from the mid- to late 7th century, and another in the Classical period.

70. Rose 1995, pp. 89-93, figs. 15-19.

71. Blegen 1937, pp. 586-588; Troy IV, pp. 273-279. See also Basedow 2009, p. 137. 


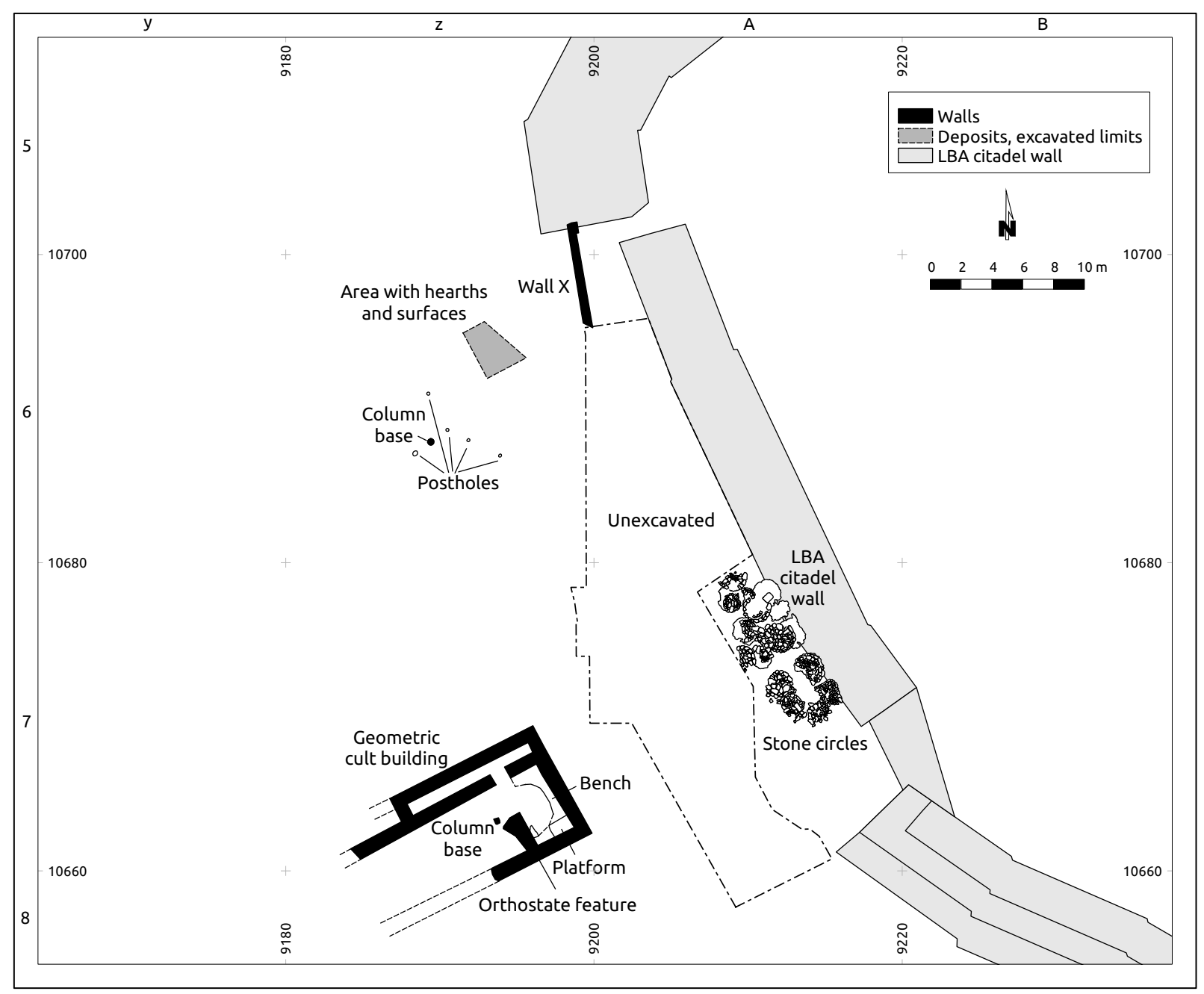

Figure 22. Plan of the West Sanctuary, Late Geometric-Early Archaic phase. P. Hnila. Courtesy the Troia Project in diameter from 1.85 to $2.25 \mathrm{~m}$, and some are built over others. Black ash covered many of them, sometimes interspersed with layers of sand. The pottery from this area was published as a group, without any indication of stratigraphic relationships. ${ }^{72}$ The majority of the sherds are G2/3 ware and gray ware, indicating that the circles were in use at the same time as the Place of Burning. Two bird kotylai support a date in the 8th century for the use of the circles or an underlying building (House 850; see below). ${ }^{73}$ The published pieces do, however, include a few from the Late Archaic and Hellenistic periods. The excavation notebooks indicate that several of these later sherds were found in the levels above the stone circles or associated with the Roman grandstand adjacent to the platform. ${ }^{74}$

The Early Archaic pottery from this area published by Blegen includes a number of shapes that could have been used for dining, in both painted G2/3 ware and gray ware, some of which is highly decorated with incision. Among the published sherds are 15-16 large kraters and dinoi, an

72. Troy IV, pp. 275-279.

73. Troy IV, p. 256, fig. 303:9, 10.

There is also a skyphos with pendent semicircles from this area that may date to the 9th or 8th century (Troy IV, p. 279, no. VIII.124, fig. 303:8).

74. Rawson notebook 1936, vol. 5. 

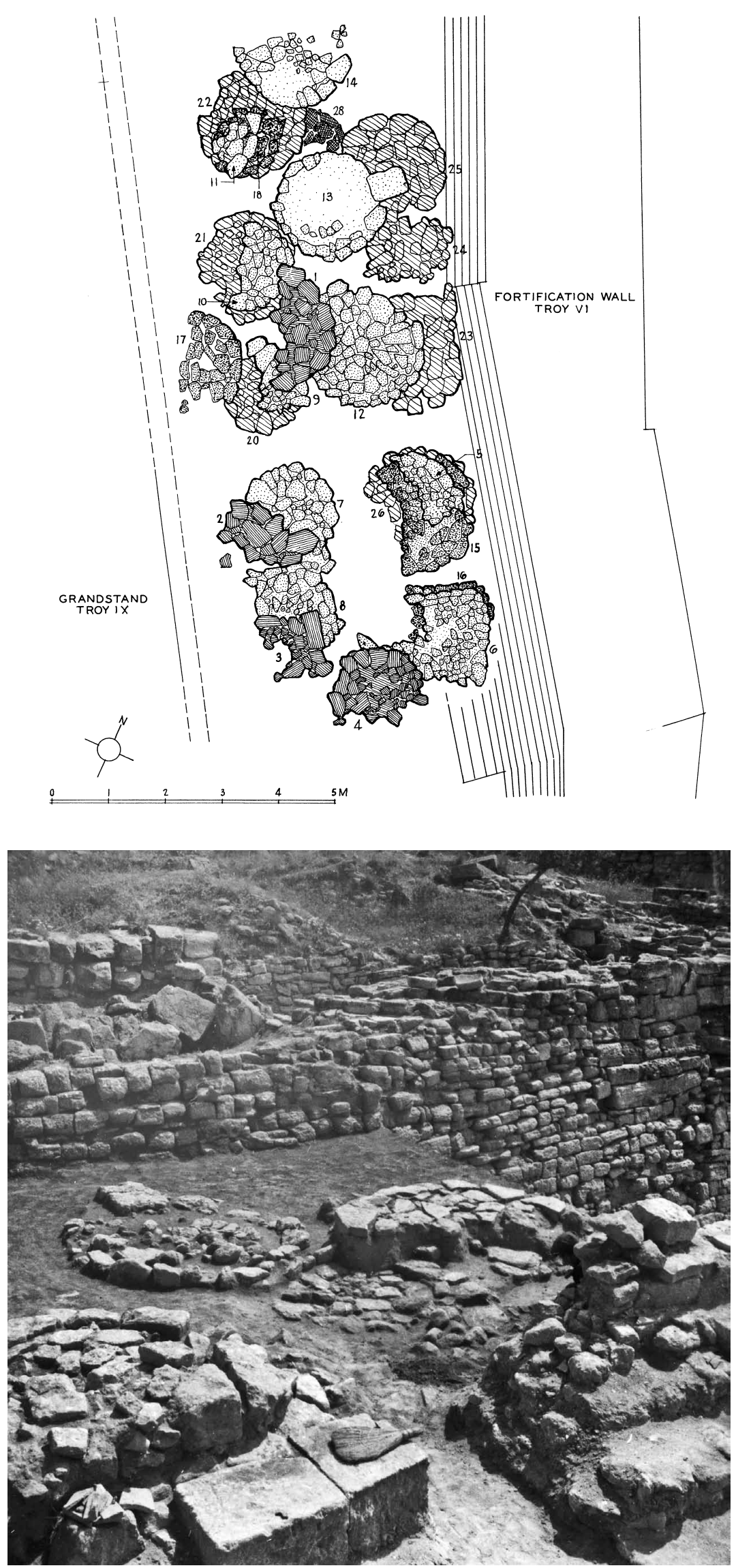

Figure 23. West Sanctuary: plan of the stone circles. Troy IV, fig. 369. Courtesy Department of Classics, University of Cincinnati
Figure 24. West Sanctuary: the stone circles from the west. Troy photo T.37.6.7. Courtesy Department of Classics, University of Cincinnati 


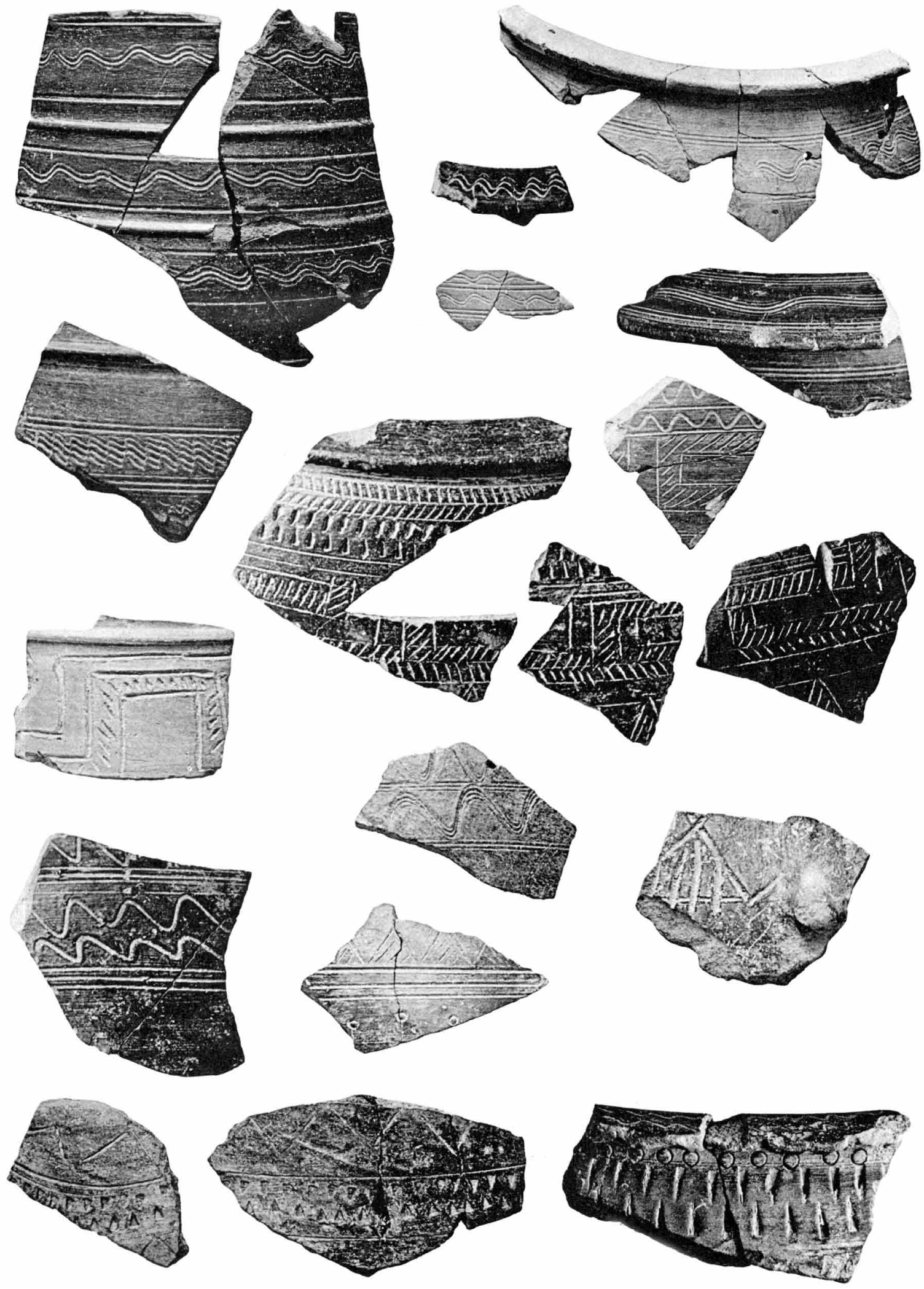

Figure 25. Gray ware kraters and dinoi found in the area of the stone circles in the West Sanctuary.

After Troy IV, fig. 301. Courtesy Department of Classics, University of Cincinnati 
unusual concentration of such vessels (Fig. 25). ${ }^{75}$ Jugs and drinking cups are also present. ${ }^{76}$ This material supports the interpretation of the stone circles at Troy, like those at Asine, Mycenae, Nichoria, Naxos, Kyme, and Miletos, as places for ancestor cult and funerary meals, or more generally for ritual feasting. ${ }^{77}$ Stone circles within a ritual area have also recently been found at Lefkandi. ${ }^{78}$ An earlier example of a stone circle within an apsidal building was discovered at Klazomenai, although in this case the ritual function is less clear. ${ }^{79}$

For someone approaching the sanctuary from the west, the temple and the stone circles were aligned to create a visual axis that would have drawn attention to the Late Bronze Age citadel wall behind them. In the middle of the sanctuary stood the temple, behind it and on a platform ca. $3 \mathrm{~m}$ higher were the stone circles, and directly behind them rose the impressive fortification wall of Troy VI. When the stone circles were in use, those standing in the sanctuary would have been able to see both the temple and the circles where, perhaps, fires were burning, rituals were conducted, and objects such as large kraters were on display. The placement of the circles on the high platform, with the wall as a backdrop, created an impressive space for performance and display.

An interesting aspect of this arrangement of features is that it appears to be rooted in earlier periods. The Geometric temple was built in the same location as a Late Bronze Age building, the so-called Terrace House, which was left in ruins after its destruction in the Troy VIIa period. ${ }^{80}$ Some of the LBA finds from the Terrace House, including a bronze male figurine, ${ }^{81}$ a vessel in the form of a bull, ${ }^{82}$ and specialized pottery such as stands, ${ }^{83}$ suggest that the Terrace House may have had religious functions in that period. ${ }^{84}$ As early as the Late Protogeometric period, the Bronze Age structure had become a place for ritual deposits in pits both in front of and within the building, which would have been partly in ruins but still visible (Fig. 26). The contents of the pits included fenestrated stands, fragments of kraters, cups, and bowls, and enigmatic, pronged ceramic objects (Fig. 27).$^{85} \mathrm{It}$ is likely that these were votives or religious equipment. The decision to build the Geometric cult building in the same location was probably a deliberate attempt to assert the antiquity of the cult and claim a connection with the past.

The area occupied by the stone circles also shows signs of earlier ritual use. The circles were set on top of House 850, which in turn was built over House 791 (Fig. 26). The latter, constructed next to the Troy VI citadel

75. Troy IV, pp. 275-279, fig. 300, no. VIII.88, fig. 301, nos. 2, 3, 5-11, 13-16, fig. 303, nos. 6, 7.

76. Troy IV, pp. 275-279, fig. 301, no. 12 , fig. 302 , nos. $37.972,4,6$.

Fig. 303:1 and 2 could be jugs or cups.

77. Cf. Hägg 1983 (Asine); Lambrinoudakis 1988, p. 238 (Naxos); Sapouna-Sakellaraki 1998, pp. 69-70 (Kyme). See also Antonaccio 1995, pp. 199-207, 250, 256.

78. Lemos 2008, structure C; the associated pottery is LH IIIC-Middle PG. There is evidence (kraters, cooking pots, and animal bones) that eating and drinking took place outside the structure.

79. Aytaçlar 2004, p. 19.

80. For the LBA architecture and pottery of the Terrace House, see Becks, Rigter, and Hnila 2006. 81. Mellink and Strahan 1998. 2004.
82. Rigter and Thumm-Doğrayan
83. Two of the stands are Mycenaean (Mountjoy and Mommsen 2006, pp. 108, 110, nos. 70, 71, fig. 8). A gray ware fenestrated stand may also belong to this period.

84. Becks, Rigter, and Hnila 2006, pp. 79-80; Becks 2008.

85. For preliminary reports, see Rose 1997, pp. 82-83; 1998, pp. 74-76. The pits will be published in detail in the final report on the West Sanctuary. 


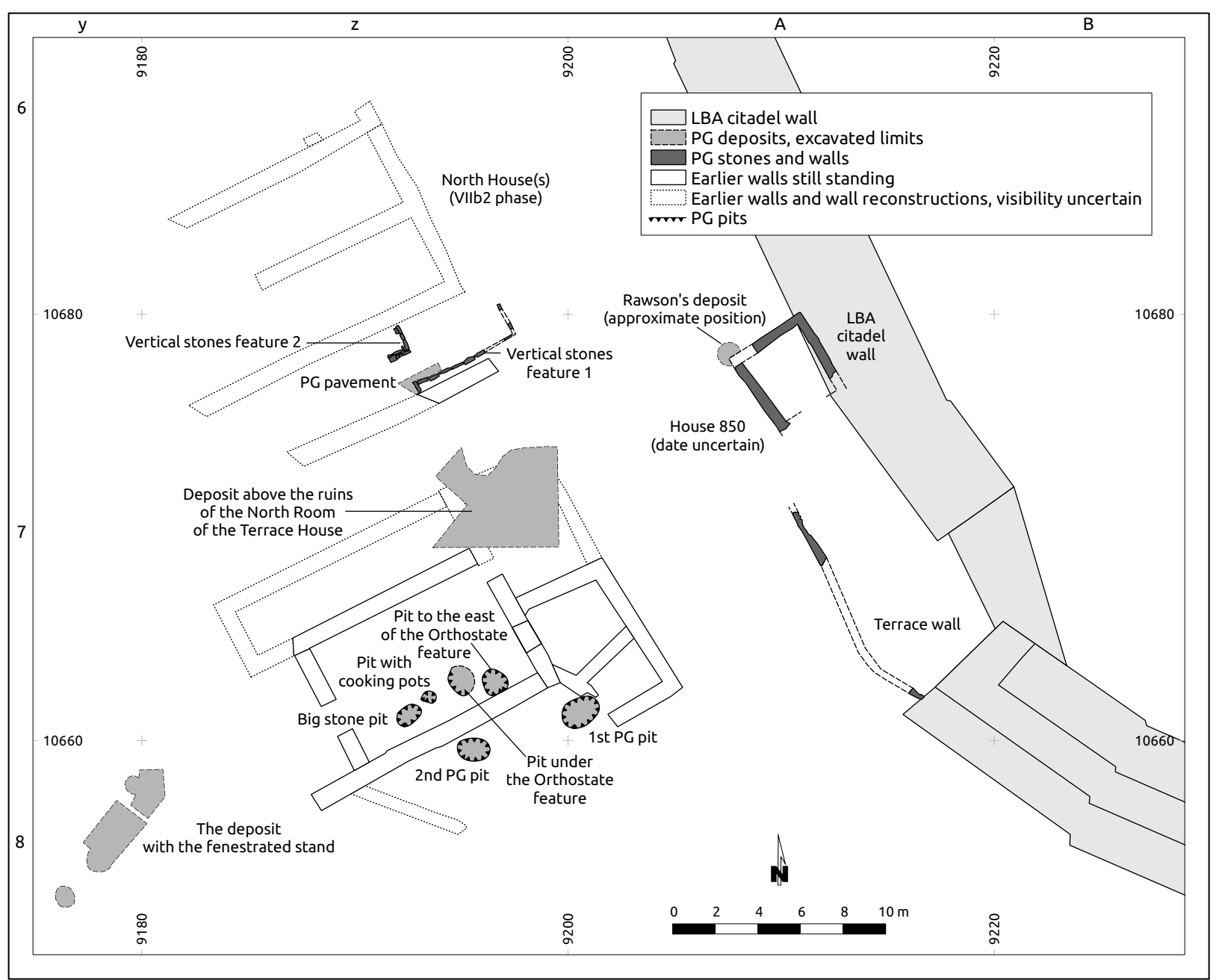

Figure 26. Plan of the West Sanctuary, Protogeometric phase. P. Hnila. Courtesy the Troia Project

86. Troy IV, pp. 241-243. See also Hnila 2009.

87. Basedow 2009, p. 135.

88. Troy IV, pp. 273-274, fig. 300, no. 37.968 , fig. 302 , nos. 37.971 ,

wall, dates to the Troy VIIb2 period (Late Bronze Age-Early Iron Age); its ruins formed the platform or terrace on which the later structures were placed.$^{86}$ House 850 was a small rectangular building, and Basedow has argued that it was a religious structure.$^{87} \mathrm{On}$ stratigraphic grounds it must be dated between Troy VIIb2 and the Late Geometric-Early Archaic period.

Outside House 850, Blegen's team found another Late Protogeometric deposit of votive or feasting equipment, although it was not recognized as such at the time. ${ }^{88}$ The deposit, discovered directly outside the building while excavators were removing the walls, included a painted oinochoe, a gray ware krater, and a gray ware cup (Fig. 28). In the excavation notebook, Rawson also mentions two small pots of "kitchen ware," which were not included in the final publication, although labeled photographs are preserved in the Blegen photo archives. ${ }^{89}$ The painted and gray ware vessels

37.1070. In the publication this deposit is assigned to the Archaic period (Troy VIII).

89. Rawson notebook 1937, vol. 7, p. 82. These two pots $(37.1018,37.1019)$ are also mentioned briefly in Troy IV, p. 274. The types are found in Protogeometric deposits at Troy and perhaps begin earlier in the VIIb2 period. 

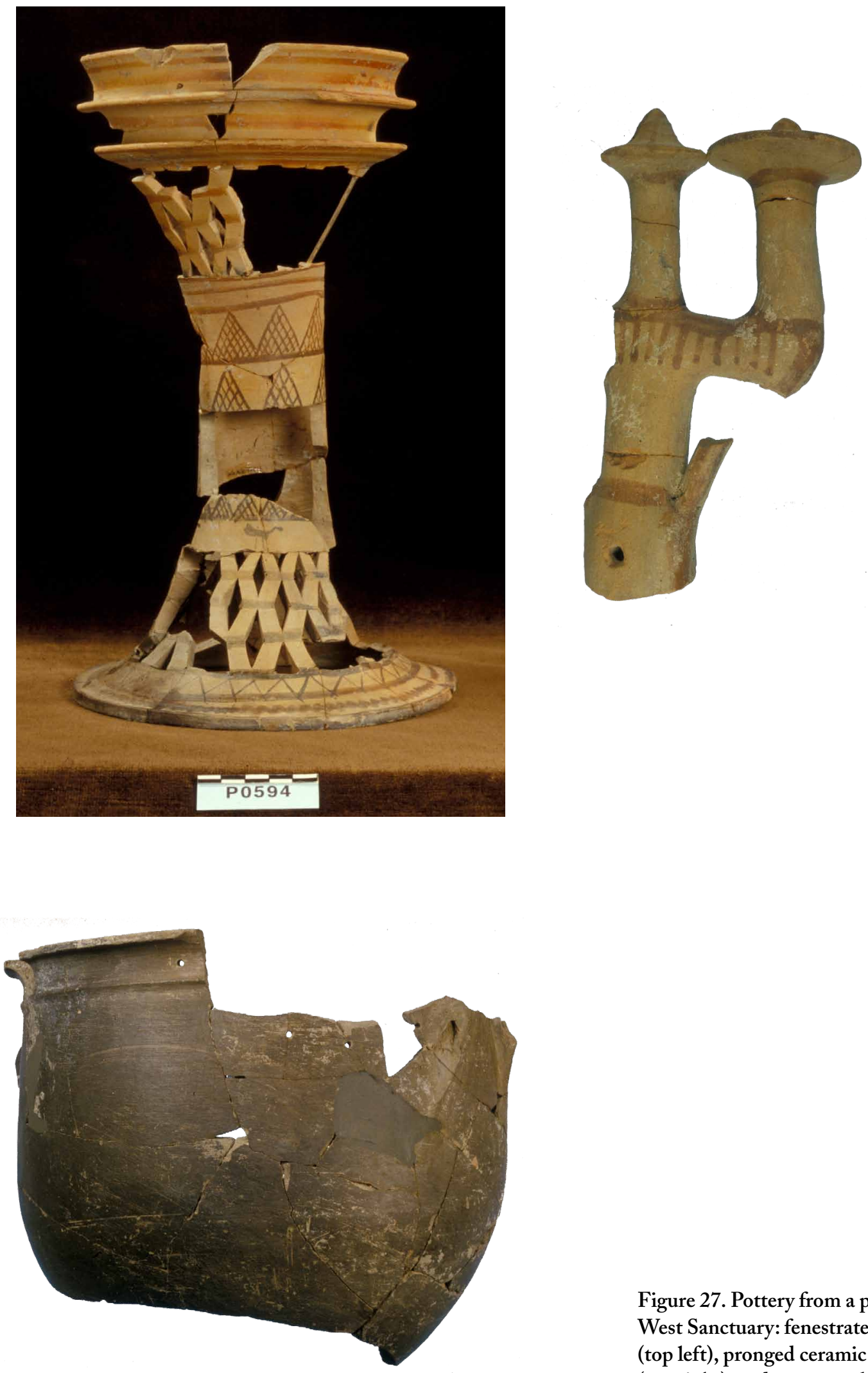

$\overline{y / 207 / 8.0444}$

Figure 27. Pottery from a pit in the West Sanctuary: fenestrated stand (top left), pronged ceramic object (top right), and gray ware krater (left). Photos courtesy Troia Project 

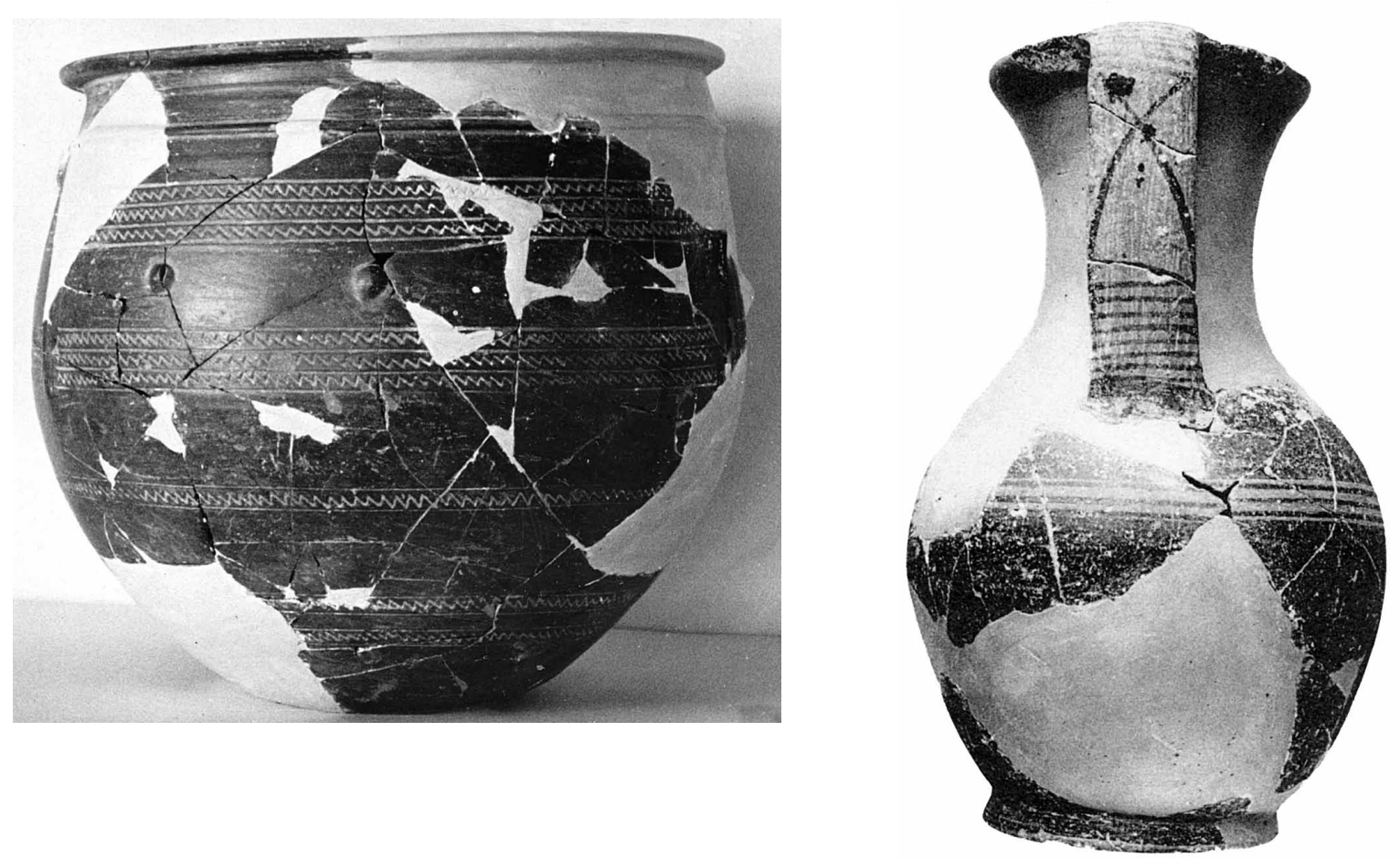

Figure 28. Pottery found near House 850 in the West Sanctuary: gray ware krater (top left), painted oinochoe (top right), and gray ware cup (right). After Troy IV, fig. 300, no. 37.1020 ; fig. 302 , no. 37.971 ; fig. 300 , no. 37.968. Courtesy Department of Classics, University of Cincinnati

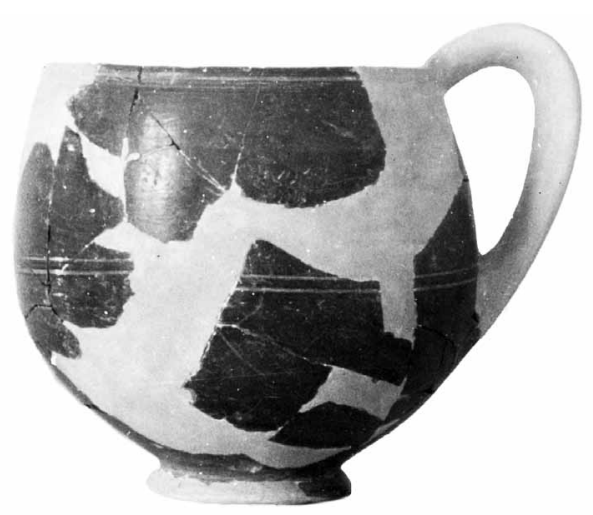

have parallels in the Late Protogeometric period. ${ }^{90}$ The large, decorated gray ware krater, in conjunction with the cup, the jug, and the two cooking pots, suggest that feasting may have taken place here already in the Late Protogeometric period, to be continued later on the same spot after the installation of the stone circles.

The West Sanctuary and the Place of Burning are two examples of sites at Troy where ritual activity took place in close proximity to Bronze Age remains. Basedow has presented evidence for ritual activity in the area of the South Gate and the Pillar House as well, although it is difficult to cf. Bayne 2000, p. 162, nos. 1-3, fig. 38. The profile of the gray ware krater (37.1070), including the vertical and horizontal ribs, resembles that of a krater found in one of the pits in front
House (P580, Fig. 27). Although both vessels are gray ware, their profiles are similar to those of painted kraters from Lefkandi and Attica: cf. Lemos 2002, pp. 48-50, nos. 74.1 (Lefkandi), 75.1 (Attica). of the entrance to the ruined Terrace resembles an Attic type: cf. Lemos 2002, pp. 68-72, nos. 35.1, 35.2 (Athens); p. 69, nos. 40.6, 40.7 (Lefis similar to PG cups from Smyrna: 
pinpoint the date of the activity, apart from the fact that it postdates the Bronze Age. ${ }^{11}$ In the West Sanctuary, votive deposits probably began in the Late Protogeometric period; only later, in the Geometric-Early Archaic period, did the inhabitants attempt to formalize the area with permanent structures and make a stronger visual connection with the LBA citadel.

The oval structure constructed in the LBA cemetery at the Place of Burning also dates to the Early Archaic period. In both cases, the ceramics include fine painted and gray ware drinking cups, jugs, and kraters, all of which could have been used in communal feasting. At the Place of Burning, it is likely that the ritual was directed toward the Bronze Age burials, whether the deceased were considered heroes or ancestors. The object of veneration in the West Sanctuary remains unknown: a deity, heroes, and ancestors are all possibilities. The position of the cult building and the stone circles, however, indicates a strong desire to make a connection with the Late Bronze Age remains.

\section{HERO AND ANCESTOR CULT}

Activity identified as hero, ancestor, or tomb cult increased in the late 8th and 7th centuries in mainland Greece, at about the same time that it intensified at Troy. The subject has been widely discussed. ${ }^{92}$ Here I highlight and discuss certain aspects of the phenomenon that are relevant to the evidence from Troy.

Archaeologists first recognized the practice when they discovered later ceramics in or around Mycenaean chamber and tholos tombs. ${ }^{93}$ Nicholas Coldstream proposed that these tombs may have been found by accident and associated with legendary heroes because of their impressive size and appearance. ${ }^{94}$ The later pottery was interpreted as votive. Antonaccio, however, has cautioned against interpreting all finds of later ceramics at Mycenaean tombs as evidence of hero cult, and she distinguishes between hero cult and tomb cult, observing that the cults known to have been specifically dedicated to named heroes are not usually located at Bronze Age tombs. ${ }^{95}$ The cults of Menelaos and Helen at Therapne and the cult of Agamemnon at Mycenae, for example, had built shrines, while the cult of Odysseus on Ithaka was in a cave. None of these was located near a Bronze Age tomb. Antonaccio does not consider the activity seen at tombs to be full cult practice, since it was of a short duration (sometimes only one visit) and consisted chiefly of the leaving of ceramics as votives. Moreover, the occupants of these tombs are anonymous, since there is no epigraphic or other evidence for their identities.

The evidence from the Place of Burning at Troy does not fit neatly into either of these categories. There is no clearly identified hero shrine, and the ceramics are more likely to be the remains of feasting than specifically votive. As noted above, the building at the Place of Burning fits better into a category of structures placed within cemeteries to accommodate rituals for the dead. At the same time, the fact that the cemetery did not contain the recently deceased suggests that rituals conducted during the
91. Basedow 2009, pp. 136-142.

Her conclusion is based on a study of the excavation notebooks, photographs, and publications by Blegen and his team, who refer to the discovery of "Troy VIII" pottery is this area. In my experience working with the notebooks from these excavations, records of "Troy VIII" pottery usually denote G2/3 ware from the Early Archaic period.

92. See, e.g., Farnell 1921; Price 1973; Coldstream 1976; Snodgrass 1980, pp. 37-40; 1982; Bérard 1982; Wright 1982; Whitley 1988, 1994; Antonaccio 1994a, 1994b, 1995; Polignac 1995, pp. 128-149; Deoudi 1999; Hägg 1999; Mazarakis Ainian 1999; Boehringer 2001.

93. Coldstream 1976, pp. 9-12; Antonaccio 1994a, pp. 392-395.

94. Coldstream 1976, pp. 13-14.

95. Antonaccio 1994b; 1995, pp. 6-7. 
Early Archaic period are more likely to fall into the category of hero or distant ancestor worship.

A third type of evidence that may be relevant is the construction of later temples on Bronze Age citadels or near Bronze Age ruins. These appear to be products of the same impulse that led to hero and tomb cult, but here the effort appears to have been focused on establishing or demonstrating the antiquity of a cult or a settlement. At Mycenae a Geometric temple was built on the citadel near the megaron of the palace; there is also evidence, albeit controversial, that the inhabitants began leaving votives in the area as early as the Protogeometric period. ${ }^{96}$ Several other areas of the site were centers of hero or ancestor cult as well, as attested by a shrine to Agamemnon outside the citadel and votives left at tombs. ${ }^{97}$ The pattern seen at Myceneae, in which attention was paid to a variety of Late Bronze Age remains, resembles that at Troy, which also shows signs of activity in several different areas, including the Place of Burning, the West Sanctuary, and the South Gate.

The inhabitants of Tiryns likewise established a cult of Hera on the site of the Mycenaean megaron in the mid-8th century, probably refurbishing an earlier LH IIIC building. A votive deposit found nearby dates from the 8th to the mid-7th century. ${ }^{98}$ Cult buildings of the Archaic period set near or on Bronze Age remains are also known from several settlements in Crete. ${ }^{99}$

In the Argive Heraion, James Wright has proposed that the Old Temple terrace was built in a Cyclopean style to make it look like a much older Mycenaean citadel. In the absence of impressive Late Bronze Age ruins, he argues, the inhabitants of Argos built an imitation in order to give the site and the cult ancient status. ${ }^{100}$ Wright's interpretation of the building activity at the Argive Heraion as an attempt to give a sense of the antiquity of the cult can help us understand the West Sanctuary at Troy, where the location of the temple on top of a Late Bronze Age structure, and in close proximity to the Late Bronze Age fortification wall, may have been a way for the inhabitants to make the cult seem ancient and long established.

An important question at all of these sites, and especially at Troy, is whether the attention given to the Bronze Age remains was specifically associated with named epic heroes. Scholars have long debated whether the Homeric epics inspired an upsurge in hero cult, or, conversely, whether veneration of local heroes contributed to the epics. ${ }^{101}$ Coldstream argues that the circulation of epic poetry was probably a factor in some areas that experienced a change in population after the Late Bronze Age, but that in other areas local heroes may have been worshipped throughout the Iron Age. ${ }^{102}$ By contrast, Whitley doubts that the veneration of named epic heroes was important before the 6th century. ${ }^{103}$ Antonaccio and Whitley have cautioned that there is little evidence that tomb cults were associated with Homeric or other heroes; instead, they claim, later inhabitants may have made offerings more generally to their ancestors. ${ }^{104}$ Inscriptions or graffiti on dedicated objects might help to settle the matter of identity, but such documents are unknown at Troy until the 6th century, and even then they remain quite rare. The same is true of votives such as figurines that 
might be attributed to a specific hero, since no figurines from the 8 th or early 7 th century have been found anywhere at Troy.

This debate has implications for the interpretation of the ritual activity at the Place of Burning. The burials in the Bronze Age cremation urns found at the site would have been fairly simple, containing few objects of wealth, and perhaps would not have seemed especially remarkable or heroic. By contrast, we know from ancient authors that in later periods the conspicuous tumuli near Troy were thought to be the graves of Achilles, Patroklos, and Ajax. ${ }^{105}$ Already in the Iliad we find references to the tombs of Trojan ancestors as markers in the landscape: Hector joins other Trojans for a council of deliberation at the tomb of Ilos $(10.414 ; 11.166$, 371), the army gathers at the burial mound of Myrina (2.814), and the tomb of Aesyetes serves as a lookout point (2.786-793). There is certainly disagreement about whether Homeric descriptions of the Trojan landscape were based on an actual knowledge of the region. Still, it is intriguing that the Iliad mentions these heroic grave monuments, along with the mound of Patroklos and Achilles described in the Odyssey (24.76-84), and it is possible that already in the 8th century the inhabitants of Troy associated features in the landscape with Greek or Trojan heroes. ${ }^{106}$

Attempts to identify the locations of the burial mounds of the Trojan ancestors still lack archaeological confirmation. ${ }^{107}$ Excavations at Sivritepe (the so-called tumulus of Achilles) have shown that the base of the tumulus was a Neolithic site; in the Hellenistic period, builders added to its size to make it appear more impressive. ${ }^{108}$ It is not entirely clear when the other tumuli near Troy were constructed or when they began to be associated with the Homeric heroes. ${ }^{109}$ Brian Rose has suggested that at least by the late 7 th century, the Athenian settlers at Sigeion may have chosen their site because of its proximity to the tumuli of Achilles, Patroklos, and Ajax. ${ }^{110}$

If there were indeed tumuli or other features of the landscape associated with the burials of both Trojan and Greek heroes, one wonders why a cemetery of simple cremation urns would have become a location for communal feasting. There are, however, other examples, such as those noted above at Athens and Eleusis, of simple tombs becoming objects of interest in later periods. Because Troy has such a prominent place in the Homeric epics, it is tempting to interpret ritual activity near Bronze Age tombs at the site as Homeric hero worship; nevertheless, it is equally possible that the activities at the Place of Burning may have been associated with local ancestors or a more general cult of the dead, rather than with specific Homeric heroes.

105. E.g., Strabo 13.1.32 (C 595596). For a list of heroic relics, shrines, and tombs from various areas, including the Troad, see Thompson 1985, pp. 95-330. See also Cook 1973, pp. 159-165; Burgess 2009, pp. 112-126.

106. Price (1973) has suggested that references to the tomb of Ilos as well as other passages in the Iliad and the
Odyssey show that Homer was aware of hero-cult practices. 107. See Luce 2003, pp. 13-22, for an attempt to locate the tombs of Myrina, Ilos, and Aesyetes. See also Cook 1973, p. 172.

108. Rose 1999, pp. 61-63; 2000, pp. 65-66; 2008, p. 418, n. 113. 109. Cook 1973, pp. 163-164, 173-
174. The earliest pottery found in excavations at the tumuli seems to be Archaic black figure (6th-early 5th century) or Archaic gray ware that cannot be dated more precisely. See also Burgess 2009, pp. 112-126.

110. Rose 2008, p. 418. See also Cook 1973, p. 186; Demir 2004; 2007, pp. 556-557; Bieg and Aslan 2006. 
Whitley follows Anthony Snodgrass and François de Polignac in seeing hero cult not as a response to the circulation of epic poetry, but rather to sociological and political factors, including population growth, polis formation, and conflict over possession of land. ${ }^{111}$ Tomb and ancestor cults linked to Bronze Age monuments may have been ideological tools used to solidify a group's identity and strengthen control over its territory. Snodgrass interprets hero cult as an attempt to lay claim to land in areas where a free peasantry competed for ownership. ${ }^{112}$ Others see the phenomenon as part of a materialization of political ideology, either as a reaction to newcomers by established residents or as a form of competition between newly emerging elites. Whitley has argued that at Argos tomb cult was a political act tied to an ideological claim to a territory, a claim to which other elites in the region reacted in a competitive way by establishing tomb cults of their own. ${ }^{113}$ Explanations of this sort fit well with the situation in the Troad, where similar developments, such as the arrival of newcomers and competition to establish control of territory, are likely to have occurred in the late 8th and early 7 th centuries, as part of more widespread changes in the northeastern Aegean at this time.

\section{REGIONAL DEVELOPMENTS IN THE TROAD AND NORTHEASTERN AEGEAN}

An examination of the Troad and northeastern Aegean from the Early Iron Age to the Archaic period reveals a possible connection between developments in the region and the increase in ritual activity associated with Late Bronze Age remains. During the transition from the Late Bronze Age to the Early Iron Age (Troy VIIb2), immigrants from Thrace settled at Troy, bringing with them a tradition of handmade pottery and building houses in many areas of the site. ${ }^{114}$ By the end of Troy VIIb2, the structures near the perimeter of the citadel were no longer occupied. ${ }^{115}$ It is likely that the population had decreased, perhaps drawing closer into the center of the citadel.

In this phase, Protogeometric amphoras began to appear, as well as some gray ware imitations of painted Protogeometric cups; earlier types of handmade and gray wares also continued in use. ${ }^{116}$ The distribution patterns of Protogeometric amphoras point to trading networks in the northeastern Aegean. ${ }^{117}$ Whether the small number of new ceramic types is a product of an Aiolian migration or, more likely, indicates trade and increasing interaction between communities in western Anatolia and the Greek mainland has recently been a subject of scholarly discussion. ${ }^{118}$

111. Snodgrass 1980, pp. 37-40; Polignac 1995, pp. 128-140; Whitley 1988. See also Antonaccio 1994b; 1995 , pp. 6-8, 252-268.

112. Snodgrass 1980, p. 39.

113. Whitley 1988 , pp. $180-181$.
114. For the VIIb period at Troy, see Troy IV; Becks 2006; Becks, Hnila, and Pieniążek-Sikora 2006; Rose 2008, pp. 409-411; Hnila 2009.

115. Hnila 2009. I thank the author for information from his manuscript.
116. Catling 1998; Lenz et al. 1998; Aslan 2002, 2009a; Rose 2008, pp. 412-413.

117. Catling 1998.

118. See, e.g., Hertel 1992, 2007, 2008b; Parker 2008; Rose 2008. 
The 9th century at Troy, as elsewhere in the northeastern Aegean, is not very well known. ${ }^{119}$ The cult building in the West Sanctuary, however, together with a small amount of pottery, indicates some activity at the site. ${ }^{120}$ The population grew again in the 8th and early 7 th centuries. The ceramic type marker for this period is the later form of $\mathrm{G} 2 / 3$ ware, which has been found in abundance at Troy. ${ }^{121} \mathrm{In}$ the Troad, the only known site with activity of this period is Troy itself, which seems to have been a regional center, although it is likely that future research will reveal other contemporaneous settlements. Sites with G2/3 ware also appear on Lesbos, Lemnos, Tenedos, Samothrace, and Thasos; some of these are new settlements, while others may represent a growth in population at previously established sites. ${ }^{122}$ Few imports arrived at Troy from farther afield: only a handful of vessels may have come from Samos and Chios, and a scant two or three pieces of Lydian pottery have been found; bird bowls are also very rare. ${ }^{123}$ It appears that Troy did not have many far-reaching contacts and that the northeastern Aegean formed a fairly closed cultural unit at this time.

The reasons for the growth in the number of sites and the appearance of a new pottery style at this time are not entirely evident. G2/3 ware is distinctive when compared with other Geometric pottery, such as that from Samos or Athens. Although vague similarities in shapes and certain motifs are detectable, there does not appear to be evidence for large movements of peoples with new pottery traditions into the Troad from other regions. The fact that earlier and later forms of the ware have been identified at Troy perhaps indicates that it developed there or in the Troad and subsequently spread elsewhere. ${ }^{124}$

There is, however, some limited evidence, although admittedly from much later historical sources, to suggest that external groups may have been extending their power into the Troad at this time. ${ }^{125}$ Strabo (13.1.22 [C 590]) writes that when the Milesians wanted to found a colony at Abydos in the northern Troad, they first asked the Lydian king Gyges for permission. This story implies Lydian control of the Troad during the first part of the 7th century. ${ }^{126}$ Thucydides (8.62.1) also notes that the Milesians established a colony at Abydos, although he does not mention Lydian interest in the area. If the Lydians or Milesians were indeed active in the Troad, their presence is not attested by an increase in Lydian or East Greek pottery, at least not at Troy.

119. There is no certain 9th-century material from Lesbos, although PG amphoras and 8th-century ceramics are attested (Spencer 1995). I am not aware of any certain 9th-century ceramics from Samothrace, Tenedos, Lemnos, Imbros, or any other sites in the Troad. A similar lack of material from the 9th to the mid-8th century has also been noted at Klazomenai, where Ersoy (2004, pp. 43-44) and Aytaçlar (2004, p. 31) have suggested that part of the problem may be an incorrect under- standing of the ceramic sequence, and that $P G$ pottery may in fact have been in use in western Anatolia much longer than previously thought.

120. Among the material published by Hertel (2008a) from the Schliemann collection in Berlin are additional pieces that may date to the 9th or 8th century. Even so, the total amount of pottery from these centuries is small.

121. Troy IV, pp. 253-255; Fisher 1996; 2000, pp. 80-86; Aslan 2002, 2009b; Hertel 2008a, pp. 120-162; 2008b, pp. 60-65, 94-95, figs. 44:a, 46:a, 47:a.

122. See n. 25 , above.

123. For examples of mid- to late Archaic ceramics at Troy, see Aslan 2002, pp. 110-124.

124. See n. 26, above.

125. See Burn 1960, pp. 98-105.

126. See Leaf 1923, pp. 116-117;

Tenger 1999, p. 127. The date of the establishment of Abydos has not yet been determined archaeologically (Cook 1973, pp. 56-57). 
The increase in population, new settlements in the region, and perhaps the activities of Lydians or Milesians may have put pressure on the inhabitants of Troy to express their control over the area by emphasizing their ancestry and the antiquity of their settlement. Alternatively, the Trojans themselves may have attempted to extend their control over the surrounding area, again using their illustrious past to enhance their status and strengthen their claims to power and territory. The ritual activity may also have had internal motives, to reinforce communal bonds or to legitimize the power of a local ruler or family.

Whether, by the early 7th century, Troy was accepted as the site of the Trojan War, and whether the local inhabitants were trying to take advantage of this status by the institution of hero cults, are questions that are difficult to answer conclusively. No inscriptions, works of art, or diagnostic votives support these claims. It is certainly possible that the ritual activities conducted at the Place of Burning and in the West Sanctuary were part of a local, non-Homeric ancestor cult, and that Troy's Homeric status was not emphasized until the Athenians established a colony at Sigeion in the late 7th century. On the other hand, the emphasis placed on the Late Bronze Age citadel wall and the ruin of the Terrace House, as well as the fact that this activity began well before the founding of the Athenian colony, suggest that the Homeric credentials of the site had been established at least by the early 7th century, and perhaps even earlier.

A destruction at Troy around the middle of the 7th century put an abrupt halt to population growth and political expansion or consolidation. The evidence for the destruction includes layers of rubble covering the early-7th-century remains in sectors $\mathrm{K} 4 / 5$ and D9, as well as the cessation of ritual at the Place of Burning and in the West Sanctuary. ${ }^{127}$ The exact causes of the destruction are unknown; an earthquake or an attack are both possible. ${ }^{128}$ The rubble, burned debris, and broken pottery at the Place of Burning were probably a result of this event. The production of G2/3 ware at Troy appears to have stopped, and the site may have been abandoned for a short time.

When people returned in the late 7th century, they rebuilt the West Sanctuary, but with a new arrangement of buildings and altars. The earlier cult building and the stone circles passed out of use. The votive material from this phase indicates worship of a goddess connected with swans and other wild animals. ${ }^{129}$ An influx of East Greek, Corinthian, and imitation Attic wares attests to the increasing presence and influence of Athenians and Milesians in their nearby colonies at Sigeion and Abydos. The Place of Burning appears to have been forgotten. 


\section{REFERENCES}

Akurgal, E. 1983. Eski Izmir 1: Yerleşme Katları ve Athena Tapınağı, Ankara.

Antonaccio, C. M. 1994a. "Contesting the Past: Hero Cult, Tomb Cult, and Epic in Early Greece," AJA 98, pp. 389-410.

. 1994b. "Placing the Past: The

Bronze Age in the Cultic Topography of Early Greece," in Placing the Gods: Sanctuaries and Sacred Space in Ancient Greece, ed. S. E. Alcock and R. Osborne, Oxford, pp. 79-104.

- 1995. An Archaeology of Ancestors: Tomb Cult and Hero Cult in Early Greece, Lanham, Md.

Arslan, N., and N. Sevinç. 2003. "Die eisenzeitlichen Gräber von Tenedos," IstMitt 53, pp. 223-250.

Aslan, C. C. 2002. "Ilion before Alexander: Protogeometric, Geometric, and Archaic Pottery from D9," Studia Troica 12, pp. 81-130.

- 2009a. "End or Beginning? The Late Bronze Age to Early Iron Age Transition at Troia," in Forces of Transformation: The End of the Bronze Age in the Mediterranean. Proceedings of an International Symposium Held at St. John's College, University of Oxford, 25-26th March 2006 (Themes from the Ancient Near East, BANEA Publication Series 1), ed. C. Bachhuber and R. G. Roberts, Oxford, pp. 142149.

- 2009b. "New Evidence for a Destruction at Troia in the Mid 7th century B.c.," Studia Troica 18, pp. 33-58.

- 2009c. "Swan Imagery at the West Sanctuary at Troia," in SOMA 2007. Proceedings of the XI Symposium on Mediterranean Archaeology, Istanbul Technical University, 2429 April 2007 (BAR-IS 1900), ed. Ç. Ö. Aygün, Oxford, pp. 54-60.

Aytaçlar, N. 2004. "The Early Iron Age at Klazomenai," in Klazomenai, Teos, and Abdera: Metropoleis and Colony. Proceedings of the International Symposium Held at the Archaeological Museum of Abdera, 20-21 October 2001, ed. A. Moustaka, E. Skarlatidou, M.-C. Tzannes, and Y. Ersoy, Thessaloniki, pp. 17-42.
Bammer, A. 1982. "Forschungen im Artemision von Ephesos von 1976 bis 1981," AnatSt 32, pp. 61-88.

Basedow, M. A. 2000. Beşik Tepe: Das spätbronzezeitliche Gräberfeld (Studia Troica Monographien 1), Mainz.

- 2006. "What the Blind Man

Saw: New Information from the Iron Age at Troy," in Common Ground: Archaeology, Art, Science, and Humanities. Proceedings of the XVIth International Congress of Classical Archaeology, Boston, August 23-26, 2003, ed. C. C. Mattusch, A. A. Donohue, and A. Brauer, Oxford, pp. 88-92.

. 2009. “Blegen's Late Bronze Age-Early Iron Age Transitional Stratigraphy in Light of New Evidence from Troy," in Forces of Transformation: The End of the Bronze Age in the Mediterranean. Proceedings of an International Symposium Held at St. John's College, University of Oxford, 25-26th March 2006 (Themes from the Ancient Near East, BANEA Publication Series 1), ed. C. Bachhuber and R. G. Roberts, Oxford, pp. 131-142.

Bayne, N. 2000. The Grey Wares of North-West Anatolia in the Middle and Late Bronze Age and the Early Iron Age and Their Relation to the Early Greek Settlements (Asia Minor Studien 37), Bonn.

Becks, R. 2006. "Die Unterstadt von Troia VI/VII im 2. Jahrtausend v. Chr., unter besonderer Berücksichtigung des westlichen Unterstadtviertels: Stratigraphie, Architektur, Befunde, und Funde" (diss. Univ. of Tübingen).

- 2008. "Ein Kultbau der Spätbronzezeit in Troia," in Cult and Sanctuary through the Ages (from the Bronze Age to the Late Antiquity). Proceedings of the International Symposium, Castá-Papiernička, 16-19 November 2007 (Anodos: Studies of the Ancient World 6-7/20062007), Trnava, pp. 61-72.

Becks, R., P. Hnila, and M. PieniążekSikora. 2006. "Troia in der frühen Eisenzeit: Troia VIIb1-VIIb3," in 
Troia: Archäologie eines Siedlungsbügels und seiner Landschaft, ed. M. O. Korfmann, Mainz, pp. 181188.

Becks, R., W. Rigter, and P. Hnila. 2006. "Das Terrassenhaus im westlichen Unterstadtviertel von Troia," Studia Troica 16, pp. 27-88.

Bérard, C. 1982. "Récupérer la mort du prince: Hérö̈sation et formation de la cité," in La mort, les morts dans les sociétés anciennes, ed. G. Gnoli and J.-P. Vernant, Cambridge, pp. 89105.

Bernard, P. 1964. "Céramiques de la première moitié du $\mathrm{VII}^{\mathrm{e}}$ siècle à Thasos," BCH 88, pp. 77-146.

Beschi, L. "Ceramiche arcaiche di Lemno: Alcuni problemi," ASAtene 81, pp. 303-349.

- 2003b. "Il primitivo Telesterio del Cabirio di Lemno (campagne di scavo 1990-1991)," ASAtene 81, pp. 963-1022.

Bieg, G., and R. Aslan. 2006. "Eine Quellhöhle in Spratt's Plateau (Subaşı Tepe): Wo lag Sigeion?” Studia Troica 16, pp. 133-146.

Blegen, C. W. 1932. "Excavations at Troy 1932," AJA 36, pp. 431451.

-1937. "Excavations at Troy, 1937,” AJA 42, pp. 553-597.

Boehringer, D. 2001. Heroenkulte in Griechenland von der geometrischen bis zur klassischen Zeit: Attika, Argolis, Messenien (Klio Beiheft 3), Berlin.

Burgess, J. S. 2009. The Death and Afterlife of Achilles, Baltimore.

Burn, A. R. 1960. The Lyric Age of Greece, New York.

Burr, D. 1933. "A Geometric House and a Proto-Attic Votive Deposit," Hesperia 2, pp. 542-640.

Catling, R. 1998. "The Typology of the Protogeometric and Sub-Protogeometric Pottery from Troia and Its Aegean Context," Studia Troica 8, pp. 151-187.

Coldstream, J. N. 1976. "Hero-Cults in the Age of Homer," JHS 96, pp. 8-17.

. 2000. "Evans's Greek Finds: The Early Greek Town of Knossos, and Its Encroachment on the Borders of the Minoan Palace," BSA 95, pp. 259-300.
Cook, J. M. 1973. The Troad: An Archaeological and Topographical Study, Oxford.

Danile, L. 2008. "La cultura materiale tra la fine dell'Età del Bronzo e gli inizi dell'Età del Ferro," in Hephaestia 2000-2006: Ricerche e scavi della Scuola archeologica italiana di Atene in collaborazione con il Dipartimento di archeologia e storia delle arti dell' Università di Siena. Atti del Seminario, Siena, Certosa di Pontignano, 28-29 maggio 2007, ed. E. Greco and E. Papi, Athens, pp. 39-54.

2011. La ceramica grigia di Efestia dagli inizi dell'Età del Ferro all'Età Alto-Arcaica (Lemno 2. Scavi ad Efestia 1. Monografie della Scuola Archeologica di Atene e delle Missioni Italiane in Oriente 20), Athens.

Demir, M. 2004. "On the Possible Previous Links of the Dark Age Aiolian Colonists with Their Newly Colonized Territories," Olba 9 , pp. 57-93.

. 2007. "Dark Age Aeolian Colonists: Evidence for Ancestral Relations with Their Colonial Territories," RÉA 109, pp. 541558.

Deoudi, M. 1999. Heroenkulte in homerischer Zeit (BAR-IS 806), Oxford.

Eretria $\mathrm{III}=\mathrm{C}$. Bérard, L'Hérôon à la port de l'ouest (Eretria III), Berne 1970.

Ersoy, Y. 2004. "Klazomenai, 900500 в.c.: History and Settlement Evidence," in Klazomenai, Teos, and Abdera: Metropoleis and Colony. Proceedings of the International Symposium Held at the Archaeological Museum of Abdera, 20-21 October 2001, ed. A. Moustaka, E. Skarlatidou, M.-C. Tzannes, and Y. Ersoy, Thessaloniki, pp. 43-76.

Fagerström, K. 1988. Greek Iron Age Architecture: Developments through Changing Times (SIMA 81), Göteborg.

Farnell, L. R. 1921. Greek Hero Cults and Ideas of Immortality, Oxford.

Fisher, S. M. 1996. "Troian 'G2/3 Ware' Revisited," Studia Troica 6, pp. 119-132. - 2000. "Ceramics and Culture: The Archaic Finewares of Ilion" (diss. Univ. of Cincinnati).
Foley, A. 1988. The Argolid 800-600 B.C.: An Archaeological Survey (SIMA 80), Göteborg.

Graham, A. J. 1978. "The Foundation of Thasos," BSA 73, pp. 61-98.

Hägg, R. 1983. "Funerary Meals in the Geometric Necropolis at Asine?" in The Greek Renaissance of the Eighth Century B.C.: Tradition and Innovation. Proceedings of the Second International Symposium at the Swedish Institute in Athens, 1-5 June 1981 (SkrAth 4 $\left.{ }^{\circ}, 30\right)$, ed. R. Hägg, Stockholm, pp. 189-194.

—, ed. 1999. Ancient Greek Hero Cult. Proceedings of the Fifth International Seminar on Ancient Greek Cult, Organized by the Department of Classical Archaeology and Ancient History, Göteborg University, 21-23 April 1995 (SkrAth 8, 16), Stockholm.

Hertel, D. 1992. "Über die Vielschichtigkeit des Troianischen Krieges: Die Archäologie von Troia VI, VII, und VIII," in Archäologie und historische Erinnerung: Nach 100 Jahren Heinrich Schliemann, ed. J. Cobet and B. Patzek, Essen, pp. 73-104.

. 2007. "Der aiolische Siedlungsraum (Aiolis) am Übergang von der Bronze- zur Eisenzeit," in Frühes Ionien: Eine Bestandsaufnahme. Panionion-Symposion Güzelçaml, 26. September-1. Oktober 1999 (Milesische Forschungen 5), ed. J. Cobet, V. von Graeve, W.-D. Niemeier, and K. Zimmerman, Mainz, pp. 97-122.

. 2008a. "Die frühe grieschische Keramik in der Berliner Sammlung (1020-650/625 bzw. 600/550)," in Heinrich Schliemanns Sammlung Trojanischer Altertümer: Neuvorlage (Berliner Beiträge zur Vor- und Frühgeschichte, neue Folge 14), ed. M. Wemhoff, D. Hertel, and A. Hansel, Berlin, pp. 93-174. . 2008b. Das frühe Ilion: Die Besiedlung Troias durch die Griechen (1020-650/625 v. Chr.) (Zetemata 130), Munich.

Hnila, P. 2009. "The Pottery of Troy VIIb: Chronology, Classification, Context, and Implications of Trojan Ceramic Assemblages in the Late Bronze Age/Early Iron Age Transition" (diss. Univ. of Tübingen). 
Huxley, G. L. 1966. “Troy VIII and the Lokrian Maidens," in Ancient Society and Institutions: Studies Presented to Victor Ehrenberg on His 75th Birthday, ed. E. Badian, Oxford, pp. 147-164.

Ilieva, P. 2009. “'G 2-3 Ware' and the Non-Greek Populations on the North Aegean Coast: Some Preliminary Notes on Its Distribution Patterns and Contextual Characteristics," in Greeks and Thracians in Coastal and Inland Thrace During the Years Before and After the Great Colonization. Proceedings of the International Symposium, Thasos, 26-27 September 2008, ed. Z. I. Bonias and J. Y. Perreault, Thasos, pp. 109122.

Ivantchik, A. I. 1993. Les Cimmériens au Proche-Orient (Orbis Biblicus et Orientalis 127), Freiburg.

Jablonka, P. 2006. "Vorbericht zu den Arbeiten in Troia 2005," Studia Troica 16, pp. 3-26.

Klein, N. L. 1997. "Excavation of the Greek Temples at Mycenae by the British School at Athens," BSA 92, pp. 247-322.

Kleine, J. 1979. "Milet: Bericht über die Arbeiten im Südschnitt an der hellenistischen Stadtmauer, 19681973," IstMitt 29, pp. 109-159.

Korfmann, M. 2004. "Die Arbeiten in Troia/Wilusa 2003," Studia Troica 14, pp. 3-32.

- 2005. "Die Arbeiten in Troia/ Wilusa 2004," Studia Troica 15, pp. 3-26.

Kristensen, A. K. G. 1988. Who Were the Cimmerians and Where Did They Come From? Sargon II, the Cimmerians, and Rusa I (Kgl. Danske videnskabernes selskab. Historiskfilosofiske meddelelser 57), trans. J. Laessøe, Copenhagen.

Lamb, W. 1931-1932. “Antissa," BSA 31, pp. 41-67.

Lambrinoudakis, V. K. 1988. "Veneration of Ancestors in Geometric Naxos," in Early Greek Cult Practice. Proceedings of the Fifth International Symposium at the Swedish Institute at Athens, 26-29 June 1986, ed. R. Hagg, N. Marinatos, and G. C. Nordquist $\left(\operatorname{SkrAth} 4^{\circ}, 38\right)$ Stockholm, pp. 234-246.
Lang, F. 1996. Archaische Siedlungen in Griechenland: Struktur und Entwicklung, Berlin.

Leaf, W. 1923. Strabo on the Troad: Book XIII, Cap. 1, Cambridge, Mass.

Lemos, I. S. 2002. The Protogeometric Aegean: The Archaeology of the Late Eleventh and Tenth Centuries B.C., Oxford.

—. 2008. "Lefkandi-Xeropolis 2008 Season: Region II," http://lefkandi .classics.ox.ac.uk/2008regionII.html (accessed July 25, 2011).

Lenz, D. F., F. Ruppenstein, M. Baumann, and R. Catling. 1998. "Protogeometric Pottery at Troia," Studia Troica 8, pp. 189-222.

Luce, J. V. 2003. "The Case for Historical Significance in Homer's Landmarks at Troia," in Troia and the Troad: Scientific Approaches, ed. G. A. Wagner, E. Pernicka, and H.-P. Uerpmann, Berlin, pp. 9-30.

Mazarakis Ainian, A. 1997. From Rulers' Dwellings to Temples: Architecture, Religion, and Society in Early Iron Age Greece (1100-700 B.c.) (SIMA 121), Jonsered.

- 1998. "Oropos in the Early Iron Age," in Euboica: L'Eubea e la presenza euboica in Calcidica e in Occidente. Atti del convegno internazionale di Napoli, 13-16 novembre 1996, ed. M. Bats and B. d'Agostino, Naples, pp. 179-215.

. 1999. "Reflections on Hero Cults in Early Iron Age Greece," in Hägg 1999, pp. 9-36.

Mellink, M., and D. Strahan. 1998. "The Bronze Figurine from Troia VIIa," Studia Troica 8, pp. 141150.

Messineo, G. 2001. Efestia: Scavi adriani, 1928-1930 (Monografie della Scuola Archeologica di Athene e delle Missioni Italiane in Oriente 13), Padua.

Mommsen, H.-D., D. Hertel, and P. A. Mountjoy. 2001. "Neutron Activation Analysis of the Pottery from Troy in the Berlin Schliemann Collection," AA 2001, pp. 169-211.

Moore, M. B. 1982. "The Fill of the Temenos and the Terrace: Ceramics," in Samothrace V: The Temenos, ed. P. W. Lehman and D. Spittle, Princeton, pp. 317-382. 
Mountjoy, P. A., and H. Mommsen. 2006. "A Neutron Activation Analysis of Mycenaean Pottery from Troia (1988-2003 Excavations)," Studia Troica 16, pp. 97-124.

Mylonas, G. E. 1961. Eleusis and the Eleusinian Mysteries, Princeton.

Nagy, G. 1979. The Best of the Achaeans: Concepts of the Hero in Archaic Greek Poetry, Baltimore.

Parker, H. N. 2008. “The Linguistic Case for the Aiolian Migration Reconsidered," Hesperia 77, pp. 431-464.

Polignac, F. de. 1995. Cults, Territory, and the Origins of the Greek CityState, trans. J. Lloyd, Chicago.

Price, T. 1973. "Hero-Cult and Homer," Historia 22, pp. 129-144.

Rigter, W., and D. Thumm-Doğrayan. 2004. "Ein hohlgeformter Stier aus Troia," Studia Troica 14, pp. 87100.

Rose, C. B. 1993. "The 1992 PostBronze Age Excavations at Troia," Studia Troica 3, pp. 98-116. . 1994. "The 1993 Post-Bronze Age Excavations at Troia," Studia Troica 4, pp. 75-104.

_. 1995. "The 1994 Post-Bronze Age Excavations at Troia," Studia Troica 5, pp. 81-105.

—. 1997. "The 1996 Post-Bronze Age Excavations at Troia," Studia Troica 7, pp. 73-110.

_. 1998. "The 1997 Post-Bronze Age Excavations at Troia," Studia Troica 8, pp. 71-113.
_. 1999. "The 1998 Post-Bronze Age Excavations at Troia," Studia Troica 9, pp. 35-71.

—. 2000. "Post-Bronze Age Research at Troia, 1999," Studia Troica 10, pp. 53-71.

_. 2008. "Separating Fact from Fiction in the Aiolian Migration," Hesperia 77, pp. 399-430.

Samos V = H. Walter, Frühe samische Gefässe: Chronologie und Landschaftsstile ostgriechischer Gefässe (Samos V), Bonn 1968.

Sapouna-Sakellaraki, E. 1998. "Geometric Kyme: The Excavation at Viglatouri, Kyme, on Euboea," in Euboica: L'Eubea e la presenza euboica in Calcidica e in Occidente. Atti del convegno internazionale di Napoli, 13-16 novembre 1996, ed. M. Bats and B. d'Agostino, Naples, pp. 59-104.

Schiering, W. 1989. "Pyrrha auf Lesbos: Nachlese einer Grabung," AA 1989, pp. 339-377.

Snodgrass, A. M. 1980. Archaic Greece: The Age of Experiment, Berkeley. - 1982. "Les origines du culte des héros dans la Grèce antique," in La mort, les morts dans les sociétés anciennes, ed. G. Gnoli and J.-P. Vernant, Cambridge, pp. 107-119.

Spencer, N. 1995. "Early Lesbos between East and West: A 'Grey Area' of Aegean Archaeology, BSA 90, pp. 269-306.

Tenger, B. 1999. "Zur Geographie und Geschichte der Troas," in Die Troas: Neue Forschungen III (Asia Minor
Studien 33), ed. E. Schwertheim, Bonn, pp. 103-180.

Thompson, E. T. 1985. “The Relics of the Heroes in Ancient Greece" (diss. Univ. of Washington).

Thompson, H. A. 1968. "Activity in the Athenian Agora: 1966-1967," Hesperia 37, pp. 36-72.

Troy III = C. W. Blegen, J. L. Caskey, and M. Rawson, The Sixth Settlement (Troy III), Princeton 1953.

Troy IV = C. W. Blegen, C. G. Boulter, J. L. Caskey, and M. Rawson, Settlements VIIa, VIIb, and VIII (Troy IV), Princeton 1958.

Wallace, S. 2003. “The Perpetuated Past: Re-use or Continuity in Material Culture and the Structure of Identity in Early Iron Age Crete," BSA 98, pp. 251-277.

Whitley, J. 1988. "Early States and Hero Cults: A Re-appraisal," JHS 108, pp. 173-182.

- 1994. "The Monuments That Stood before Marathon: Tomb Cult and Hero Cult in Archaic Attica," AJA 98, pp. 213-230.

Wright, J. C. 1982. "The Old Temple Terrace at the Argive Heraeum and the Early Cult of Hera in the Argolid,” JHS 102, pp. 186-201.

Y1maz, Y. 2003. "Seismotectonics and the Geology of Troia and Surrounding Areas, Northwest Anatolia," in Troia and the Troad: Scientific Approaches, ed. G. A. Wagner, E. Pernicka, and H.-P. Uerpmann, Berlin, pp. 55-76.

\section{Carolyn Chabot Aslan}

\section{Koç University}

DEPARTMENT OF ARCHAEOLOGY AND HISTORY OF ART

SARIYER, ISTANBUL $3445^{\circ}$

T UR KEY

caslan@ku.edu.tr 